\title{
Palaeogeographical significance of clay mineral assemblages in the Permian and Triassic sediments of the SE Iberian Ranges, eastern Spain
}

\author{
Jacinto Alonso-Azcárate ${ }^{\mathrm{a}}$, Alfredo Arche ${ }^{\mathrm{c}}$, José F. Barrenechea ${ }^{\mathrm{b}}$, José López-Gómez ${ }^{\mathrm{c}}$, \\ F. Javier Luque ${ }^{\mathrm{b}}$, Magdalena Rodas ${ }^{\mathrm{b}, *}$ \\ a Departamento de Geologia, Facultad de Ciencias Experimentales, Universidad de Huelva, E-21819 La Rábida, Huelva, \\ Spain \\ ${ }^{b}$ Departamento de Cristalografia y Mineralogia, Facultad de Geologia, Universidad Complutense, E-28040 Madrid, Spain

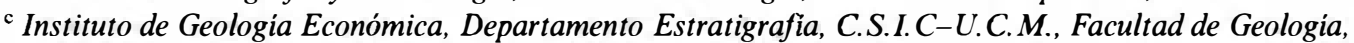 \\ Universidad Complutense, E-28040 Madrid, Spain
}

\begin{abstract}
The evolution of the palaeogeography of the SE Iberian Basin during the Permian and Triassic represents a general evolution from continental to marine environments. It has been recently studied from the sedimentological, stratigraphical, tectonic and palaeontological points of view. In spite of these results, many aspects of this palaeogeography are still a matter of discussion. In this study, clay mineralogy analysis complements previous studies representing a new aspect for understanding the evolution of the sedimentary environment and the palaeogeography of the Iberian Basin during the periods in question and thus of the palaeogeography and the location of the major high areas in the westernmost border of the Tethys sea.

In spite of late diagenetic transformations the original clay mineral associations of the Permian-Triassic sediments of the SE Iberian Ranges can be reconstructed. Seventy-seven samples of siliciclastic and carbonate sediments of these ages have been studied (SEM and XRD), revealing six new aspects that help to precise the palaeogeographical interpretation of the area:

(1) Two major mineral assemblages have been found: illite + kaolinite + pyrophyllite in the continental facies and illite + chlorite + vermiculite + mixed-layer clays in the marine facies.

(2) The Mg-rich clay minerals are here considered to be of marine origin.

(3) Active phases of basin boundary faults are marked in the sediments by the presence of pyrophyllite, derived directly from the Palaeozoic metamorphic basement.

(4) Unconformities separating major depositional sequences also separate formations with different clay mineralogy.

(5) Different groups of clay minerals can be separated clearly coinciding with the different palaeogeographical stages also distinguished in the westernmost border of the Tethys sea.

(6) The clay mineral associations back up the data of a previous hypothesis of a humid climate for the end of the Permian in the study area just prior to the first incursion of the Tethys sea. (c) 1997 Elsevier Science B.V.
\end{abstract}

Keywords: Iberian Ranges; Permian; Triassic; clay mineralogy; palaeoclimatology 


\section{Introduction}

The Iberian Ranges form a linear alpine structure trending NW-SE in the central and eastern Iberian Peninsula (Fig. 1). This intraplate structure started its development during the early Permian along a Hercynian or older suture between the Iberian Massif to the SW and the ancestral Ebro Block to the NE. The main compressive periods, with inversion tectonics, took place in the Late Jurassic-Early Cretaceous and the Late Oligocene-Early Miocene, with extension periods during the Early Permian to Late Jurassic. Cretaceous, Eocene-Oligocene and Late MiocenePliocene. There was no metamorphism and volcanic rocks were intruded in the Early Permian. Late Triassic and Middle Jurassic.

This paper deals with the Early Permian to Late Triassic rocks of the southeastern Iberian Ranges (Fig. 1). They present the classic Germanic facies trilogy of Buntsandstein. Muschelkalk and Keuper, although there are substantial facies and thickness changes (Castillo, 1974; López-Gómez and Arche, 1993a) (Fig. 2). Some recent studies have established a detailed stratigraphy of these sediments with up to $1250 \mathrm{~m}$ of total thickness, defining formations, dating most of them with reasonable precision (Doubinger et al., 1990; Márquez et al., 1994), finding regional unconformities and unravelling the complex relationship between tectonics and sedimentation (LópezGómez and Arche, 1992, 1993a,b, 1994: Arche and López-Gómez, 1996) (Fig. 3).

The objective of this work is to contribute to the knowledge of the general evolution of the SE Iberian Basin during the Permian to Triassic period with the study of the, up to now poorly known, clay mineralogy. In a broader sense, the objective is also to refine the palaeogeography of the westernmost border of the Tethys basin during the transition from the continental clastics to the first marine incursion in the study area. This study concentrates on the clay mineralogy of the fine fraction, its genetic relationship with the sedimentary environment of each formation and its detrital or diagenetic origin in sediments represented by Buntsandstein and Muschelkalk facies. Previous general studies on the mineral associa- tions of Spanish Permian and Triassic sediments can be found in Caballero and Martín-Vivaldi (1972), Ruiz Cruz and Caballero (1976a,b,c,d), Arribas (1984), Morad et al. (1989, 1990), Jeans et al. (1994), Marfil et al. (1996), and Ruiz Cruz (1996).

\section{Stratigraphy and sedimentology}

This study investigates samples from eight outcrops in the SE Iberian Ranges, including continental red beds and shallow-marine carbonates of Early Permian to Middle Triassic age (Fig. 3). The sediments are subdivided into four Depositional Sequences bounded by unconformities or hiatuses (López-Gómez and Arche. 1992, 1993a; Doubinger et al., 1990). Each sequence consists of two formations. The Tabarreña Breccias Formation is not included in the scheme of depositional sequences.

The main sedimentological and lithological characteristics of the nine formations are summarized in Table 1, and their detailed description, datation and interpretation can be found in López-Gómez and Arche (1985, 1992, 1993 a,b, 1994), Sopeña et al. (1988), López-Gómez and Mamet (1990), López-Gómez et al. (1993), Arche and LópezGómez (1996).

The Permian and Triassic sediments of the Iberian Basin were deposited under an extensional regime, in a rift basin trending NW-SE. Periods of subsidence and sediment accumulation alternate with periods of tilting, partial erosion and weathering when the unconformities and hiatuses bounding the Depositional Sequences were formed (Sopeña et al., 1988; Arche and López-Gómez, 1996). These surfaces are of regional importance and can be traced all along the Iberian Ranges.

\section{Analytical methodology}

The clay mineralogy of the Permi an and Triassic sediments of the Iberian Ranges is very poorly known. However, in the study area, each formation is measured, dated and correlated with nearby areas. Using this framework, seventy-seven 


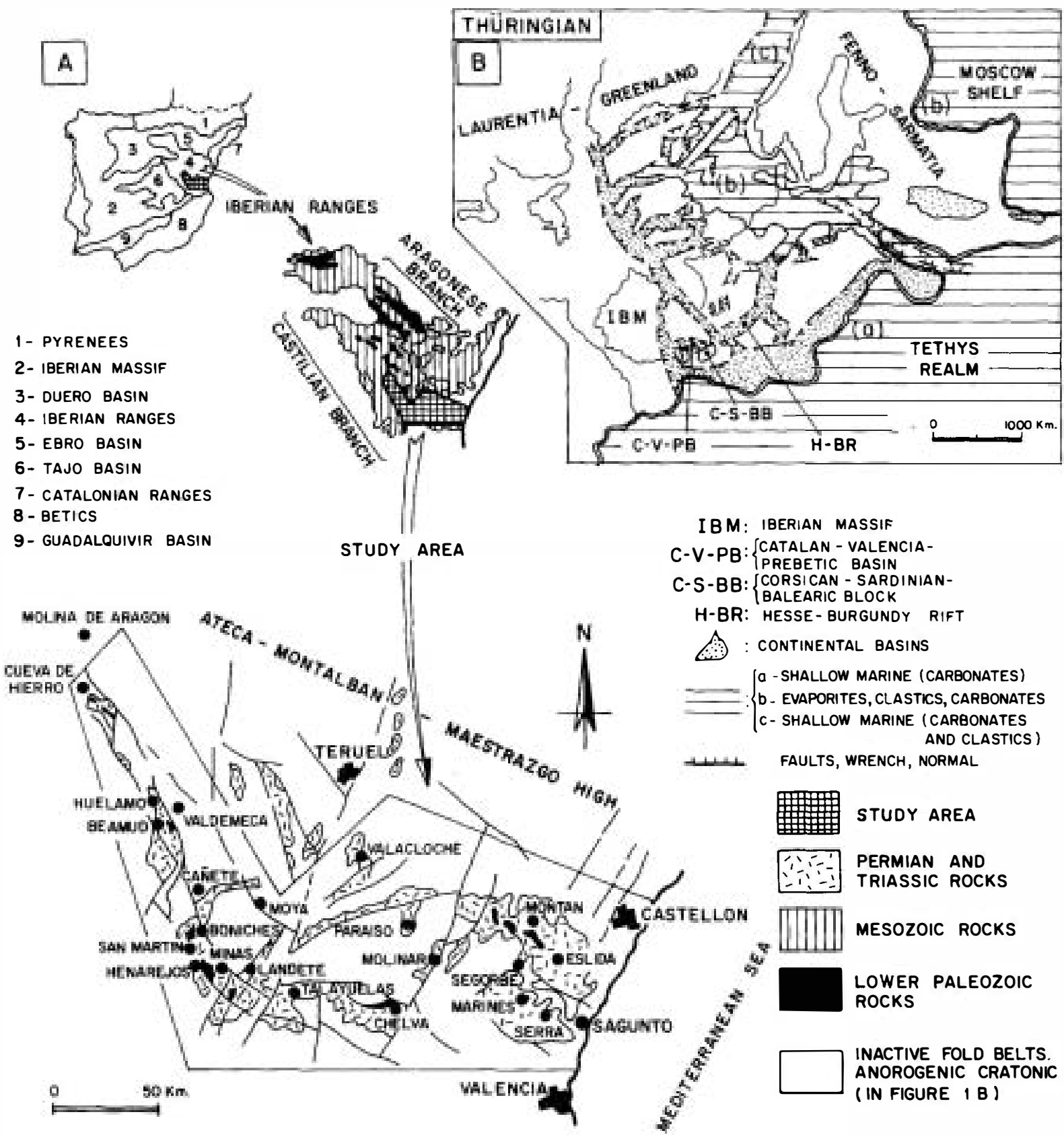

Fig. 1. A. Present sedimentary basins in the Iberian Peninsula, main outcrops of the Permian-Triassic sediments in the SE Iberian Ranges and location of the study area (modified from Arche and López-Gómez, 1996).

B. Tentative palaeogeographical reconstruction of the western Tethys realm during the Late Permian (modified from Ziegler, 1988).

samples were selected from fine-grained intervals (siltstones and marls) from both siliciclastic and carbonate units (Fig. 3). In addition, several samples of shales from the Lower Palaeozoic metamorphic basement outcropping in the margins of the basin were investigated, as they might represent 


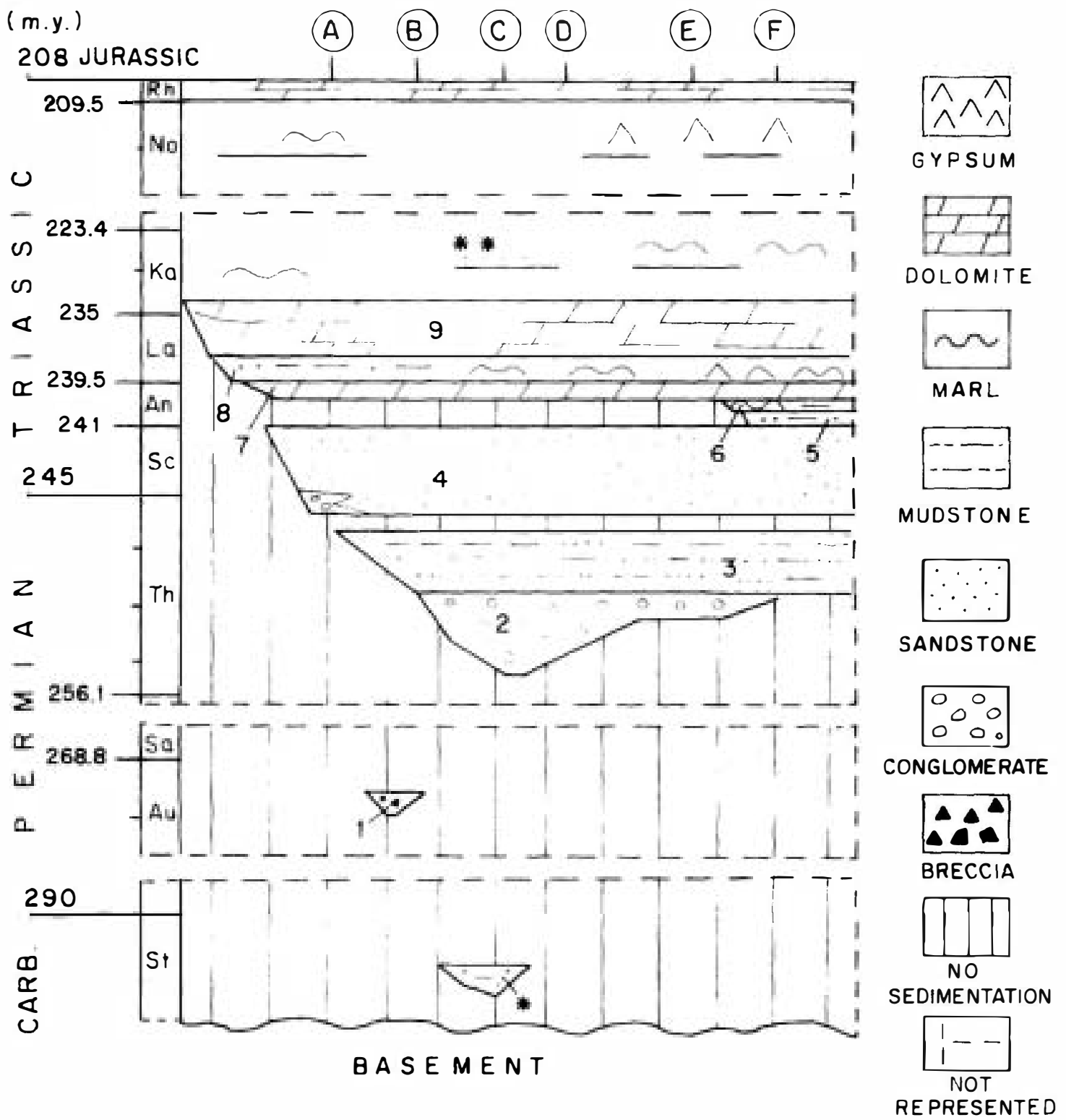

FORMATIONS: 1-TABARREÑA, 2-BONICHES, 3-ALCOTAS, 4-CAÑIZAR

5-ESLIDA, 6-MARINES, 7-LANDETE, 8-MAS, 9-CAÑETE

* * keuper facies, * coal and sandstones

LOCATIONS: A-VALDEMECA, B-BONICHES, C-HENAREJOS,

D-TALAYUELAS, E-CHELVA, F-EL MOLINAR

Fig. 2. Age, stratigraphical and geographical distribution of the Permian- Triassic sediments (formations) of the SE Iberian Ranges. Units 2-3, 4-5, 6-7 and 8-9 are Depositional Sequences bounded by unconformities. 


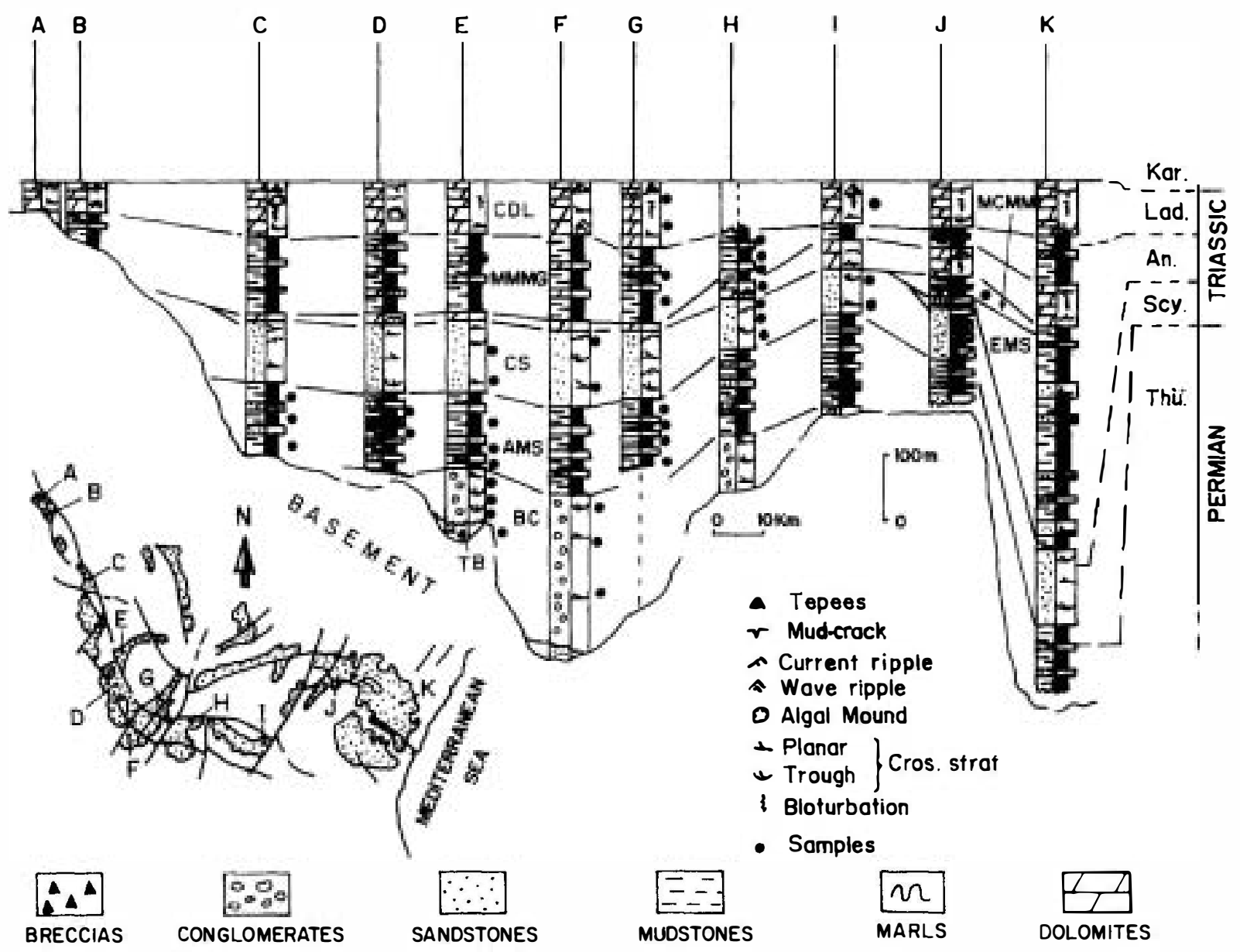

Fig. 3. Studied sections of the Permian-Triassic sediments and location of the samples (black dots). The localities are: $\mathrm{A}=\mathrm{Cueva}$ de Hierro; $\mathrm{B}=$ Masegosa; $\mathrm{C}=$ Valdemeca; $\mathrm{D}=$ Cañete; $\mathrm{E}=$ Boniches; $\mathrm{F}=$ Henarejos; $\mathrm{G}=$ Landete; $\mathrm{H}=$ Talayuelas; $\mathrm{I}=\mathrm{Chelva} \mathrm{J}=$ Segorbe; $\mathrm{K}=$ Eslida. See also Fig. 1 for their location. The formations are: $\mathrm{Tb}=$ Tabarreña; $\mathrm{BC}=$ Boniches; $\mathrm{AMS}=\mathrm{Alcotas}$; $\mathrm{CS}=\mathrm{Cañizar}$; EMS-Eslida; $\mathrm{MCMM}=$ Marines; $\mathrm{LD}=$ Landete; $\mathrm{MAMG}=\mathrm{Mas} ; \mathrm{CDL}=$ Cañete.

probable provenance areas for some of the Permian-Triassic materials.

Samples were analyzed by X-ray diffraction (XRD) and scanning electron microscopy (SEM) methods. The bulk mineralogical study was carried out using the crystalline powder diffraction method. For the study of the clay minerals, three oriented aggregates (OA) of both, the 2-20- and $<2-\mu \mathrm{m}$ fractions, were obtained by sedimentation from an aqueous suspension. The first $\mathrm{OA}$ of each fraction was air dried, the second one was heated at $550^{\circ} \mathrm{C}$ for $2 \mathrm{~h}$ and the last one was solvated with ethylene glycol (EG) at $65^{\circ} \mathrm{C}$ for $48 \mathrm{~h}$.

Samples were run on a Philips PW 1730/90 $\mathrm{X}$-ray diffractometer, using $\mathrm{Cu}-K_{\alpha}$ radiation, graphite monochromator, slits $1^{\circ}-0.2 \mathrm{~mm}-1^{\circ}$, ratemeter $1 \times 10^{3}$ to $1 \times 10^{4}$ c.p.s. at time constant $1,40 \mathrm{kV}, 30 \mathrm{~mA}$, scan rate $2^{\circ} \Delta 2 \theta / \mathrm{min}$. A scan rate of $1 \%$ min and a time constant of 2 have been employed in the powder diffractograms of the fine fractions $2-20$ and $<2 \mu \mathrm{m}$ in the range of $59^{\circ}$ to $64^{\circ}(2 \theta)$ in order to measure the $(060)$ reflection, 
Table 1

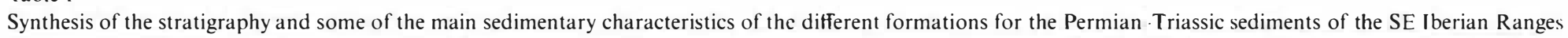

\begin{tabular}{|c|c|c|c|c|c|c|c|c|c|}
\hline \multirow{3}{*}{$\begin{array}{l}\text { Facies } \\
\text { Dep. sequence } \\
\text { Formation }\end{array}$} & \multirow{3}{*}{ Tabarreña } & \multirow{2}{*}{\multicolumn{2}{|c|}{$\frac{\text { "Saxonian" }}{\text { DS-1 }}$}} & \multirow{2}{*}{\multicolumn{3}{|c|}{$\frac{\text { Buntsandstein }}{\text { DS-2 }}$}} & \multicolumn{3}{|l|}{ Muschelkalk } \\
\hline & & & & & & & \multicolumn{2}{|l|}{ DS-3 } & \multirow{2}{*}{$\begin{array}{l}\text { DS-4 } \\
\text { Cañete }\end{array}$} \\
\hline & & Boniches & Alcotas & Cañizar & Eslida & Marines & Landete & Mas & \\
\hline Lithology & $\begin{array}{l}\text { quartzite } \\
\text { and slate } \\
\text { pebble } \\
\text { breccias }\end{array}$ & $\begin{array}{l}\text { subangular } \\
\text { quartzite } \\
\text { pebbles and } \\
\text { scarce sandy } \\
\text { matrix }\end{array}$ & $\begin{array}{l}\text { mudstones } \\
\text { alternating with } \\
\text { sandstones }\end{array}$ & $\begin{array}{l}\text { pink arkosic } \\
\text { sandstones }\end{array}$ & $\begin{array}{l}\text { red } \\
\text { mudstones } \\
\text { alternating } \\
\text { with } \\
\text { sandstones }\end{array}$ & $\begin{array}{l}\text { mudstones. } \\
\text { marls and } \\
\text { intercalated } \\
\text { sandstones }\end{array}$ & $\begin{array}{l}\text { grey } \\
\text { dolostones }\end{array}$ & $\begin{array}{l}\text { mudstones, } \\
\text { marls and } \\
\text { alternating } \\
\text { sandstones } \\
\text { and gypsum }\end{array}$ & $\begin{array}{l}\text { grey } \\
\text { dolostones }\end{array}$ \\
\hline $\begin{array}{l}\text { Maximum } \\
\text { thickness (m) }\end{array}$ & 33 & 210 & 175 & 210 & 650 & 135 & 95 & 150 & 93 \\
\hline Age & $\begin{array}{l}\text { Autunian } \\
\text { (?) }\end{array}$ & Türingian & Türingian & $\begin{array}{l}\text { Türingian } \\
\text { Anisian }\end{array}$ & Anisian & Anisian & Anisian & Anisian-Lad & iadrudinian \\
\hline $\begin{array}{l}\text { Some of the } \\
\text { main } \\
\text { characteristics }\end{array}$ & $\begin{array}{l}\text { Fe-Mn- } \\
\text { oxide } \\
\text { varnishes }\end{array}$ & $\begin{array}{l}\text { 3-4-m-thick } \\
\text { tabular } \\
\text { bodies }\end{array}$ & $\begin{array}{l}\text { lenticular } \\
\text { intercalculations } \\
\text { of the sandstone } \\
\text { bodies }\end{array}$ & $\begin{array}{l}\text { thinning- } \\
\text { upwards } \\
\text { sequences up to } \\
2.3 \mathrm{~m} \text { thick }\end{array}$ & $\begin{array}{l}\text { multistorey } \\
\text { lenticular } \\
\text { sandstone } \\
\text { bodies }\end{array}$ & $\begin{array}{l}\text { gradual } \\
\text { lateral } \\
\text { thickness } \\
\text { change }\end{array}$ & $\begin{array}{l}\text { gradually } \\
\text { pinch out } \\
\text { towards the } \\
\text { W }\end{array}$ & $\begin{array}{l}\text { very poorly } \\
\text { exposed in } \\
\text { outcrops }\end{array}$ & $\begin{array}{l}\text { severc } \\
\text { dolomitization } \\
\text { processes }\end{array}$ \\
\hline $\begin{array}{l}\text { Main } \\
\text { sedimentary } \\
\text { structures }\end{array}$ & $\begin{array}{l}\text { none or } \\
\text { some p.c.s. } \\
\text { at the top }\end{array}$ & $\begin{array}{l}\text { mainly p.c.s. } \\
\text { but also h.s. }\end{array}$ & $\begin{array}{l}\text { p.c.s.. t.c.s. and } \\
\text { c.r. }\end{array}$ & $\begin{array}{l}\text { p.c.s. h.s.. t.c.s. } \\
\text { c.r. and r.s. }\end{array}$ & $\begin{array}{l}\text { p.c.s.. c.r.. } \\
\text { l.c.s. and r.s. }\end{array}$ & $\begin{array}{l}\text { w.r. m.c. and } \\
\text { f.\&l.b. }\end{array}$ & p.c.s.. w.r. & $\begin{array}{l}\text { w.r.. c.r.. } \\
\text { m.c. }\end{array}$ & w.r. p.c.s.. m.c. \\
\hline $\begin{array}{l}\text { Palaeocurrent } \\
\text { (average) }\end{array}$ & & $\begin{array}{l}\text { base: } N \\
80 \text {;top: } N \\
130\end{array}$ & N 137 & N 160 & N170 & $\begin{array}{l}\text { NW-SE } \\
\text { bimodal }\end{array}$ & - & - & \\
\hline $\begin{array}{l}\text { Sedimentologica } \\
\text { interpretation }\end{array}$ & $\begin{array}{l}\text { slope scree } \\
\text { deposits }\end{array}$ & $\begin{array}{l}\text { alluvial fans } \\
\text { and braided } \\
\text { fluvial system } \\
\text { deposits }\end{array}$ & $\begin{array}{l}\text { braided fluvial } \\
\text { systems with } \\
\text { extensive flood- } \\
\text { plain deposits }\end{array}$ & $\begin{array}{l}\text { sandy braided } \\
\text { river deposits }\end{array}$ & $\begin{array}{l}\text { braided } \\
\text { fluvial } \\
\text { systems with } \\
\text { extensive } \\
\text { flood-plain } \\
\text { deposits }\end{array}$ & $\begin{array}{l}\text { distal fluvial } \\
\text { to estuarine } \\
\text { deposits }\end{array}$ & $\begin{array}{l}\text { Shallow } \\
\text { carbonate } \\
\text { ramp } \\
\text { deposits }\end{array}$ & $\begin{array}{l}\text { Intertidal } \\
\text { flats and } \\
\text { coastal } \\
\text { sabkha } \\
\text { deposits }\end{array}$ & $\begin{array}{l}\text { shallow } \\
\text { carbonate } \\
\text { ramps deposits }\end{array}$ \\
\hline Reference(s) & {$[1]$} & {$[2],[3]$} & {$[3],[4]$} & {$[3],[5]$} & {$[3] \cdot[6]$} & {$[7]$} & {$[8]$} & [3], [9] & {$[8],[10]$} \\
\hline
\end{tabular}

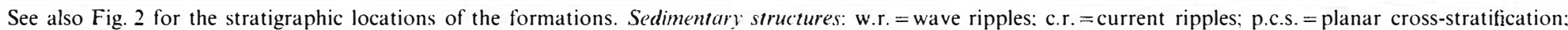

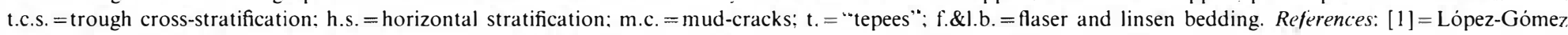

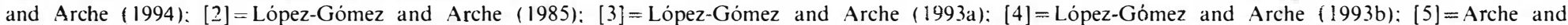

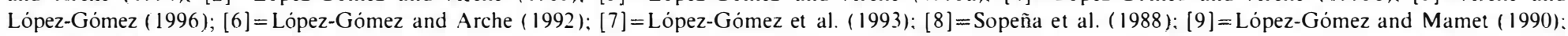
[10] = Doubinger et al. (1990) . 
using the (211) reflection of quartz as an internal standard. Illite-chlorite mixtures were treated with $\mathrm{HCl}$, to eliminate the chlorite and differentiate the reflections in this zone (Hillier, 1993).

In order to determine the degree of the postsedimentary processes that have affected these samples, the half-height width of the (illite) $10-\AA$ reflection (the so-called illite "crystallinity", IC), was measured on the $<2-\mu \mathrm{m}$ fraction diffractograms. This fraction was chosen for the IC measurements because presumably it has very small amounts of detrital material and most of the illites are authigenic (Robinson et al., 1990). However, SEM imaging is also used here for distinguishing between both detrital and authigenic phases and corroborate the results.

Using rock chip standards a calibration was performed for standardizing the IC values against the CIS data of Warr and Rice (1994). The regression line obtained is: IC (Madrid) $=$ $0.86945^{*} \mathrm{CIS}-0.00224$ and the anchizone boundaries proposed by Kübler (1967) of $0.42^{\circ}$ and $0.25^{\circ} \Delta 2 \theta$ have been used in this paper. Samples were prepared following the recommendations of the "IGCP Working Group on Illite Crystallinity" (Kisch, 1991).

The polytypes of the illite in the $<2-\mu \mathrm{m}$ fraction have been determined following the method of Caillére et al. (1982). Chlorite polytypes have proven impossible to determine because of the high percentage of illite in all the samples, overlapping the chlorite reflections in the critical interval of 2.2-2.6 $\AA$ (Hayes, 1970). In samples with high amounts of "kaolin group clay", polymorphs have been determined using the diagnostic reflections given by Ehrenberg et al. (1993).

\section{Analytical results}

The Lower Palaeozoic shales outcropping in the southwestern and northeastern margins of the basin are formed by quartz, phyllosilicates and feldspar. The clay mineral association consists of pyrophyllite, illite and chlorite (Fig. 4).

The analytical results of the clay fraction of the Permian and Triassic sediments of the SE Iberian Ranges, summarized in Fig. 5 and Table 2, indicate that these materials can be subdivided into four groups with close relationships with the four depositional sequences described previously. Three of the groups are continental facies and the uppermost one has a shallow-marine origin.

\subsection{First group}

The first group includes the Tabarreña Formation and the Boniches Formation. The bulk mineralogy (Fig. 6) consists of phyllosilicates, quartz and hematite. Minor amounts of feldspar have been found at the top of the middle and upper units within the Boniches Formation. The mineralogy of the $<2-$ and $2-20-\mu \mathrm{m}$ fractions consists of illite, kaolinite and pyrophyllite (Figs. 5 and 6), but the percentage of the latter decreases gradually towards the top of the Boniches Formation and this mineral disappears completely at the base of the upper unit. Kaolinite is the only "kaolin group clay" polymorph identified in the samples by XRD methods.

\subsection{Second group}

The second group consists of the Alcotas Formation and the Cañizar Formation. The bulk mineralogy of the Alcotas Formation includes phyllosilicates, quartz, and varying proportions of feldspar, hematite and dolomite. The clay mineralogy of the $<2$ - and $2-20-\mu \mathrm{m}$ fractions consists exclusively of illite (Figs. 5 and 6 ) and it is possible to find both authigenic and detrital particles (Fig. 7).

\subsection{Third group}

The bulk mineralogy of the Eslida Formation consists of phyllosilicates, quartz and hematite. The mineralogy of the fine fraction is formed by illite and variable percentages of pyrophyllite, that disappears towards the middle part of the formation (Figs. 5 and 8).

\subsection{Fourth group}

The fourth group consists of the Marines, Landete, Mas and Cañete Formations. The bulk 


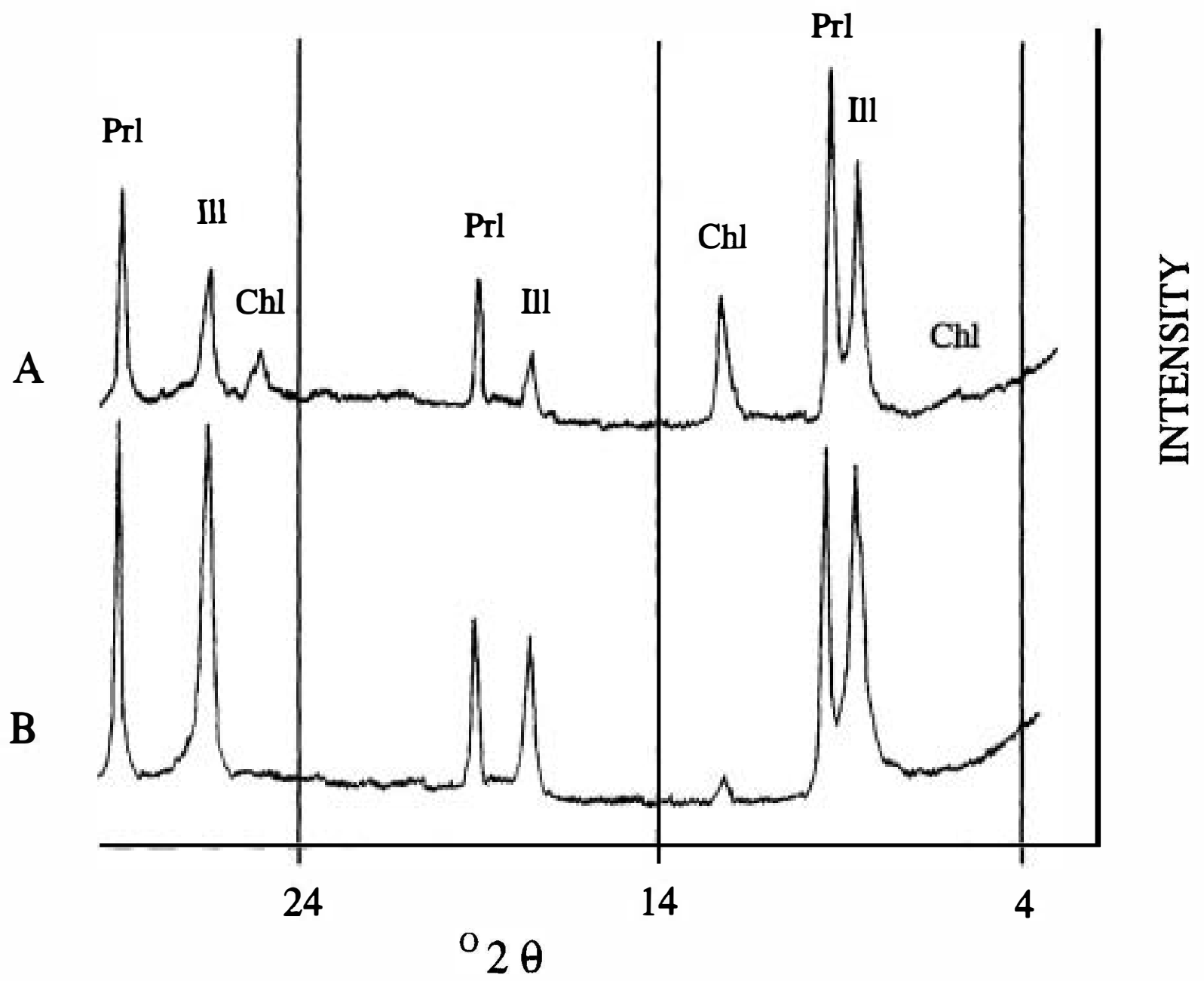

Fig. 4. X-ray diffraction traces of the air-dried oriented aggregates for the 2-20)- $\mu \mathrm{m}$ fraction from: (A) sample BAS-1 (lower Palaeozoic metamorphic slate); and (B) sample EMS-24 (Eslida Formation). 111 = illite; $\mathrm{Chl}=$ chlorite; $\mathrm{Prl}=$ pyrophyllite.

mineralogy of the Marines Formation is composed of phyllosilicates, quartz and minor amounts of feldspar and hematite. Dolomite is present in high proportions (up to 55\%) at the top of the formation. The $2-20-\mu \mathrm{m}$ fraction shows a clear vertical evolution from illi te with traces of chlorite, vermiculite and mixed-layer illite/chlorite and chlorite vermiculite in the lower half of the formation to illite and trioctahedral chlorites to the top. The $<2-\mu \mathrm{m}$ fraction has a similar composition, but chlorite is replaced by vermiculite (Figs. 5 and 9).

In the Landete, Mas and Cañete Formations the bulk mineralogy consists of dolomite, phyllosili- cates and varying proportions of calcite and quartz. The clay mineralogy of these formations changes vertically from illite \pm smectite to illite + mixed-layer chlorite/smectite (Fig. 10) and finally to illite + trioctahedral $\mathrm{Mg}$-chlorites $\left(I_{001} / I_{002}\right.$ values in the $\mathrm{X}$-ray diffraction patterns range from 1.23 to 1.42 ; Fig. 10) \pm smectite (Fig. 5). A remarkable feature within these materials is the mutually exclusive relationship observed between chlori te and dolomite (Fig. 9).

For future comparison some samples of the Keuper facies (Fig. 2) have been analysed. Bulk mineralogy consists of phyllosilicates (55-90\%), 


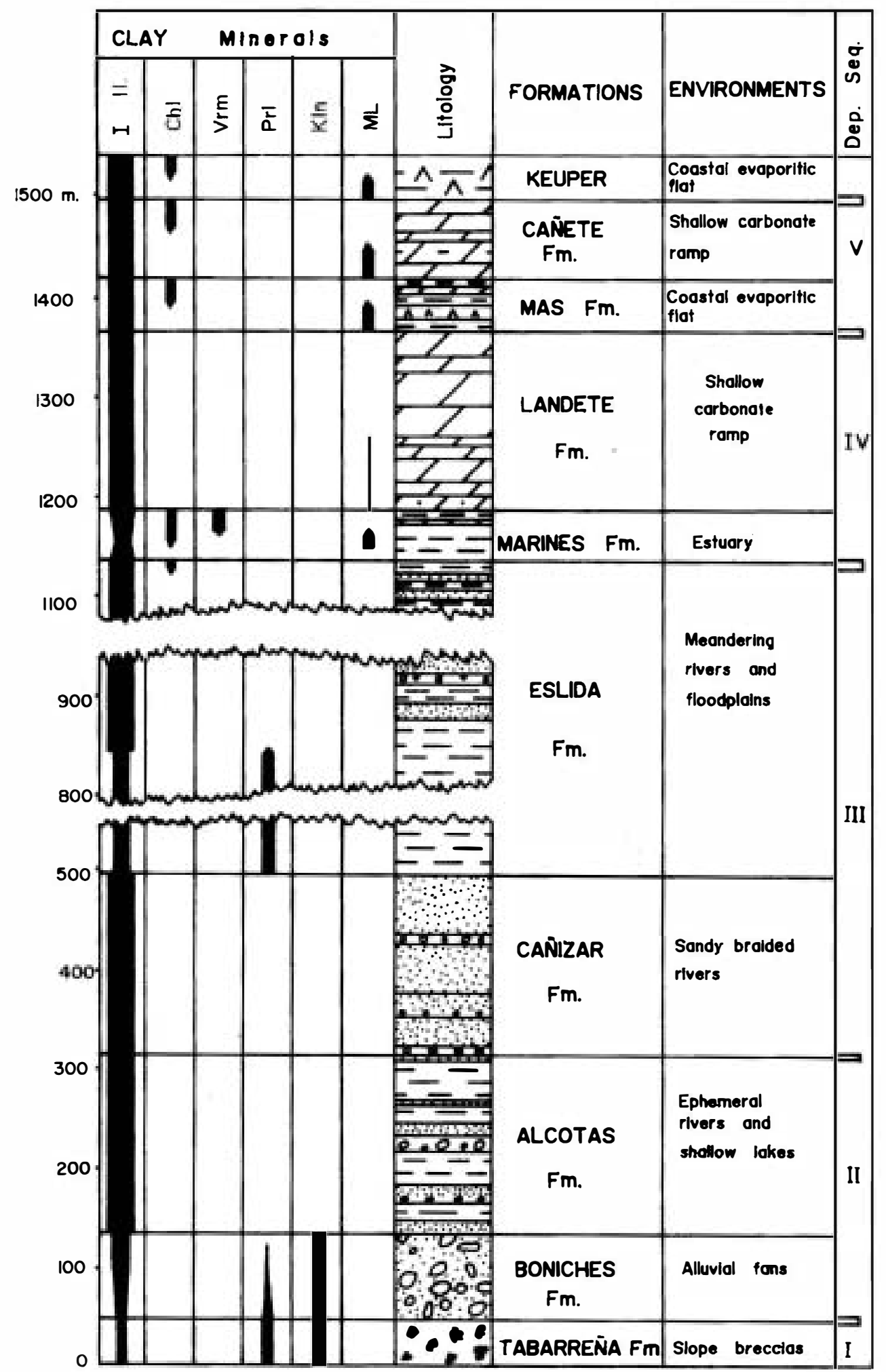

Fig. 5. Synthetic section in stages of the Permian-Triassic sediments of the SE Iberian Ranges and the distribution of clay mineral assemblages for each formation. For legend, see also Fig. 3. 
Table 2

Crystallochemical parameters of illites from the different formations

\begin{tabular}{|c|c|c|c|}
\hline \multirow[t]{2}{*}{ Formation } & \multirow[t]{2}{*}{$d_{10 \operatorname{ton} 1)}(A)$} & \multicolumn{2}{|c|}{ Crystallinity index $((2 \theta))$} \\
\hline & & mean value & range \\
\hline Tabarrena Breccias & $1.502 \pm 0 .(00)$ & $0.7(0) 7$ & $0.692 \quad 0.721$ \\
\hline Boniches Conglomerates & $1.499 \pm 0.0(02$ & 0.514 & $0.433-0.606$ \\
\hline Alcotas Mudstones and Sandstones & $1.5(0) \pm 0.000$ & 0.584 & $0.462-(0.807$ \\
\hline Canizar Sandstones & $1.5(0) \pm 0.001$ & 0.659 & $0.433 \quad 0.779$ \\
\hline Eslida Mudstones and Sandstones & $1.5\left(03^{-}\right.$ & 0.383 & $0.261 \quad 0.520$ \\
\hline Marine Clays and Marls & $1.5(0) 1 \pm 0.0(0) 1$ & (). 394 & $0.290 \quad 0.462$ \\
\hline Landete Dolostones & $1.500 \pm 0.0(02$ & 0.599 & $0.491-0.635$ \\
\hline Mas Marls and Gypsum & $1503 \pm 0.002$ & 0.868 & $0.520-1.158$ \\
\hline Canete Dolostones and Limestoncs & $1.5(02 \pm 0.0(0)$ & 0.778 & $0.721 \cdot-0.865$ \\
\hline
\end{tabular}

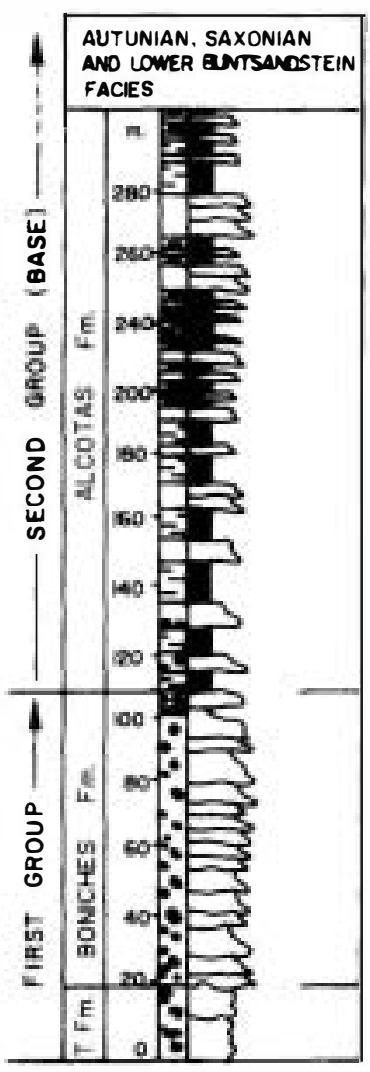

TOTAL MMERALOGY

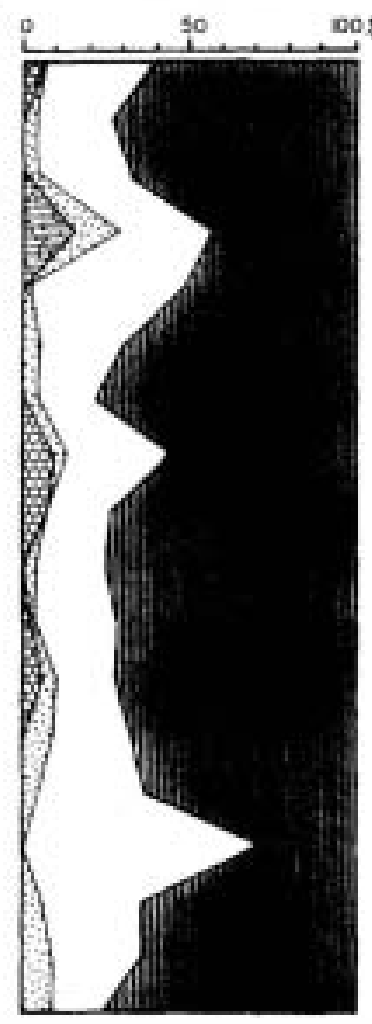

IIIII PHYLLOSUICATES

四 Dante

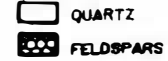

eglospars
CLAY MUERALOGY
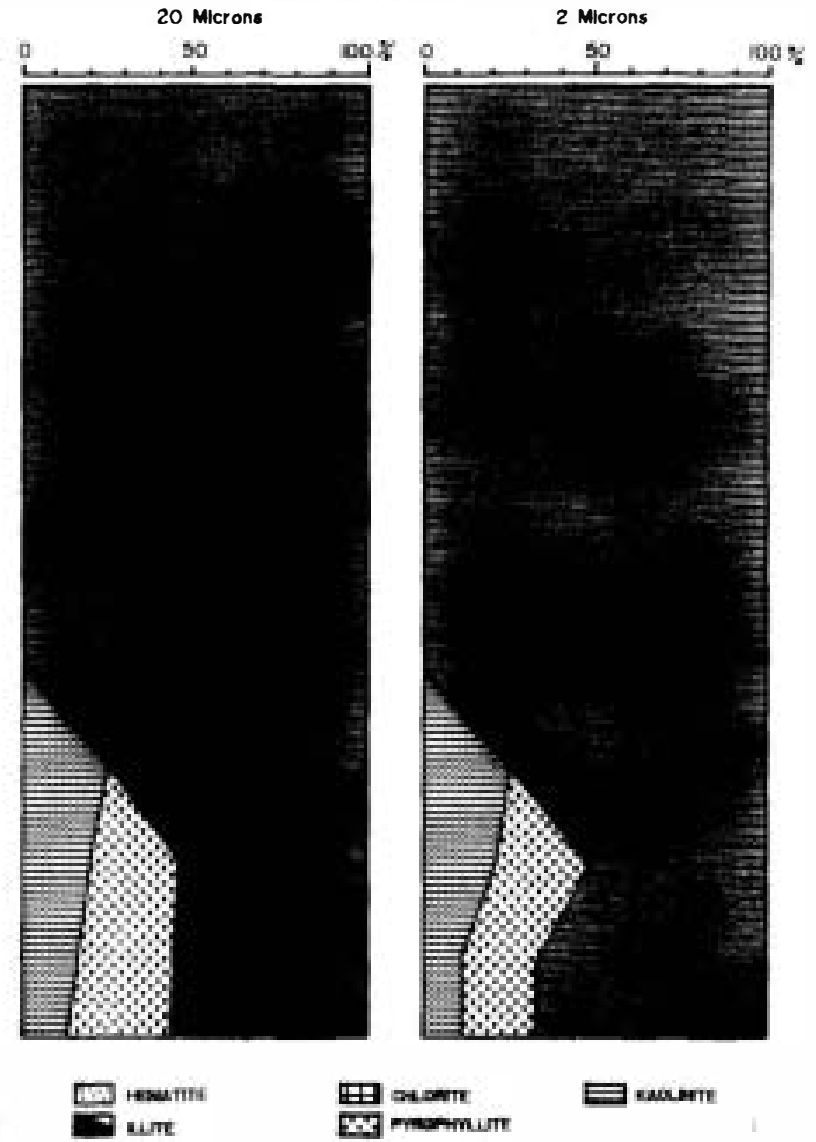

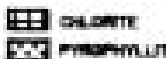

曰 eavante

Fig. 6. Bulk mineralogy and evolution of the clay mineral assemblage in the Tabarrena, Boniches (First Group) and Alcotas (base of Second Group) Formations. See also Table 2 for a more detailed sedimentological description of the section. 


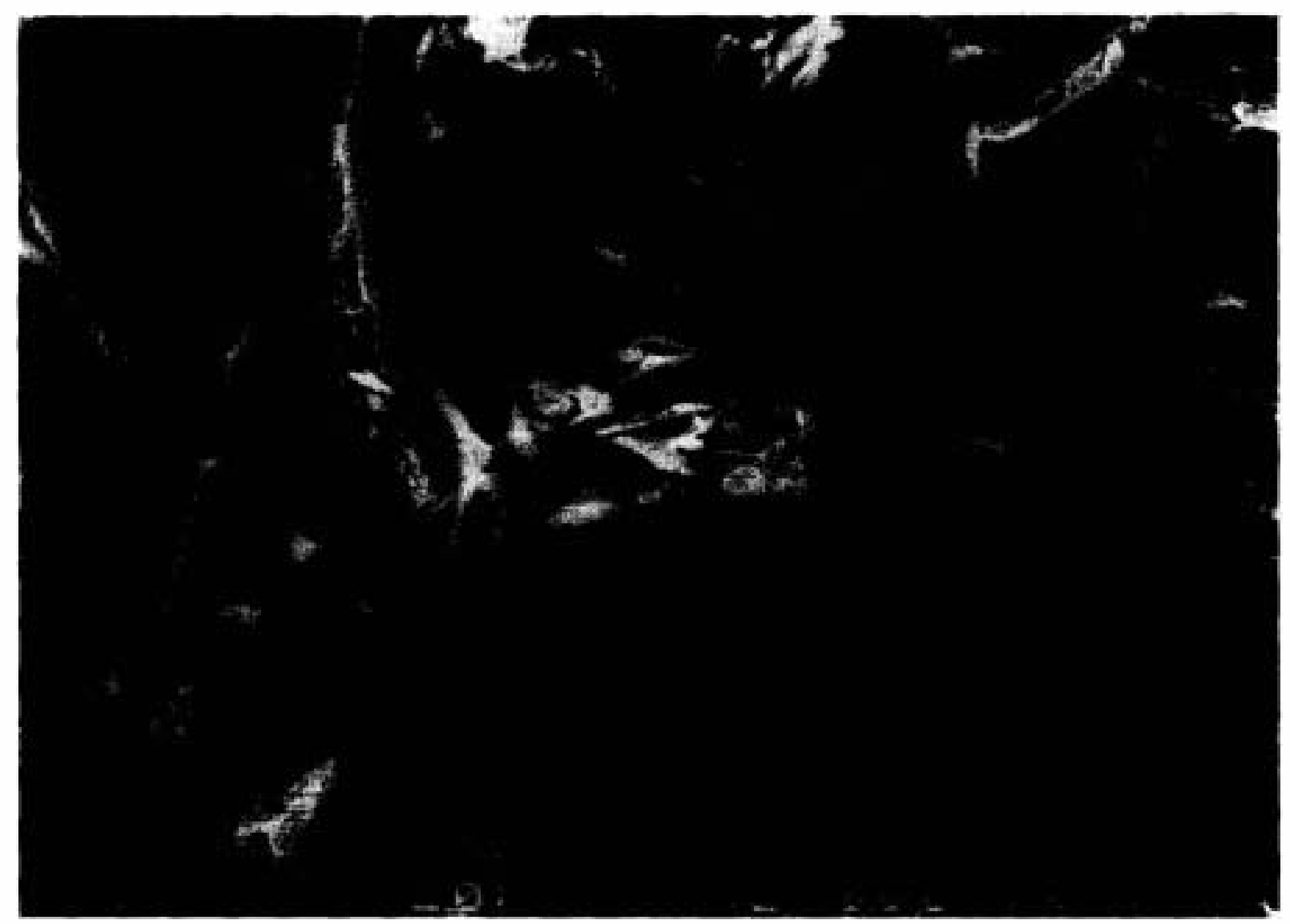

Fig. 7. Scanning electron microscopy image of authigenic illite particles together with a detrital muscovite plate.

quartz (5\%), dolomite $(0-15 \%)$ and hematite $(5 \%)$. The composition of the fine fraction (Fig. 5) changes from illite + mixed-layer chlorite/smectite to illite + trioctahedral $\mathrm{Mg}$-rich chlorite (up to $30 \%$ ), which becomes more Fe-rich towards the top $\left(I_{001} / I_{002}\right.$ ratio decreases $)$.

The general analytical results are summarized in Table 2. The most abundant clay mineral throughout the profiles is illite $(60-100 \%)$. It is a dioctahedral illite with a mean spacing $d_{(331,060)}=1.501+0.001 \AA$. These illites are mixtures of $2 \mathrm{M}_{1}$ and $1 \mathrm{M}$ polytypes in varying amounts, with a higher content of the $1 \mathrm{M}$ polytype in the marine sediments.

The illite "crystallinity" index (IC) (Kübler, 1967 ) has been determined in the $<2-\mu \mathrm{m}$ fraction of every sample. Most samples only reached diagenetic conditions, or are in the limit between the fields of diagenesis and anchizone (Table 2). In the continental sediments, the IC is somewhat lower than in the marine formations. There are some samples from the Teruel area (Eslida and Marines Formations) well into the anchizone and epizone fields. These apparently anomalous data will be discussed below.

\section{Interpretation and discussion}

Our initial hypothesis was that clay mineralogy of the Permian and Triassic formations should reflect the changes in source area, sedimentary environments and palaeocurrent patterns revealed independently by sedimentological and palaeogeographical methods. Their extrabasinal vs. intrabasinal origin could provide a means of non- 

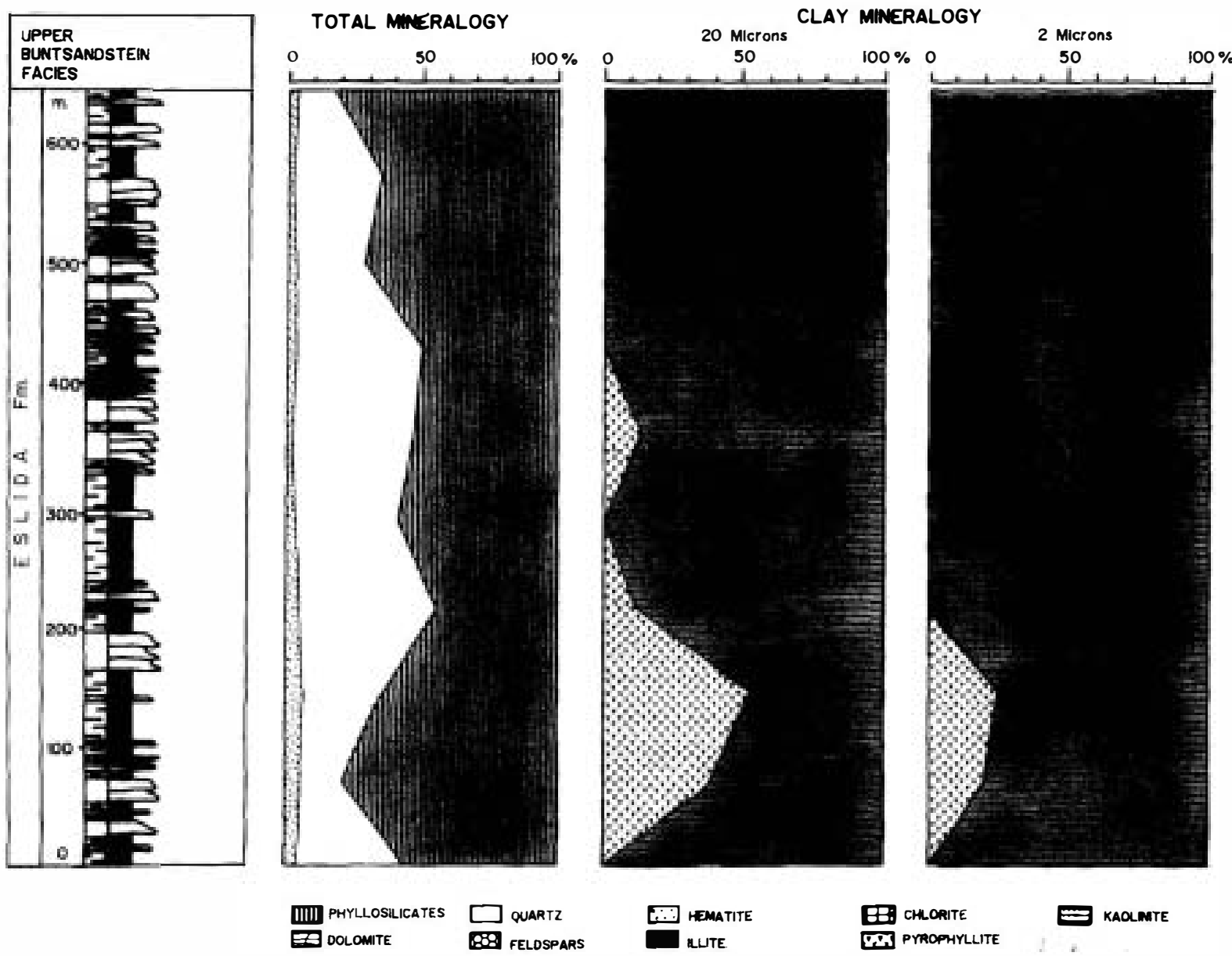

Fig. 8. Bulk mineralogy and evolution of the clay mineral assemblage of the Eslida Formation. See also Table 2 for at more detailed sedimentological description of the section.

biostratigraphic correlation and discrimination among red bed sequences which are commonly very similar in aspect. If the original clay mineralogy changes vertically and can be related to formations and environments, then it has potential to provide a means of correlation and discrimination among these red bed sequences.

Significant differences in the clay mineral associations have been observed between the continental and shallow-marine formations. Our interpretation from the main analytical results are as follows:

\subsection{First group}

The most outstanding characteristic of the Tabarreña Formation is the presence of pyrophyl- lite. This mineral is generally considered as indicative of anchizonal conditions. but in this case it seems to come directly from the OrdovicianSilurian metamorphic basement. Its high percentage (Fig. 6 ) reveals a very short transport from source area to sediment, in good agreement with the scree-type deposit inferred from the facies analysis. Pyrophyllite in these rocks is interpreted as an inherited mineral, since the breccias, according to the IC data for the $<2-\mu \mathrm{m}$ fraction, reached only the diagenetic stage and the pyrophyllite has been identified in the basement slates (Fig. 4).

The Boniches Formation shows a more complex vertical evolution. Pyrophyllite is present, but in smaller percentages than in the previous formation and decreases steadily towards the top, disappear- 


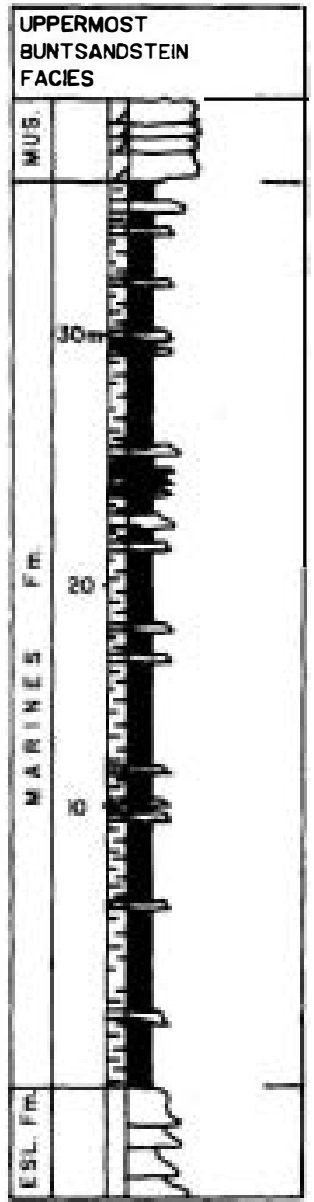

TOTAL

MUERALOGY
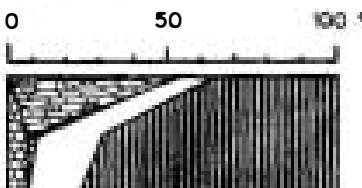

夏
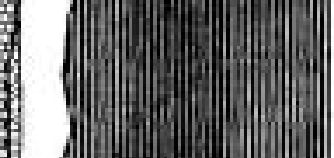

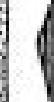

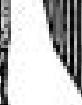
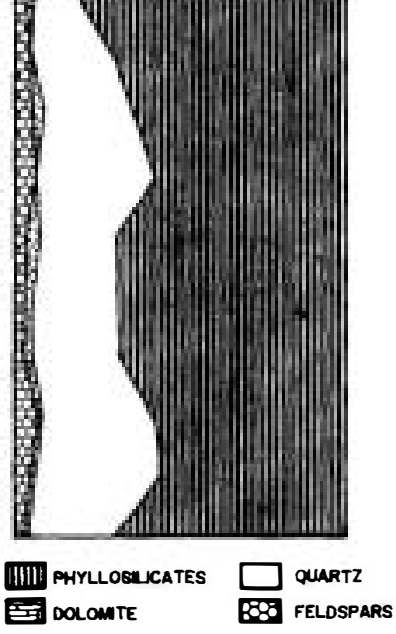

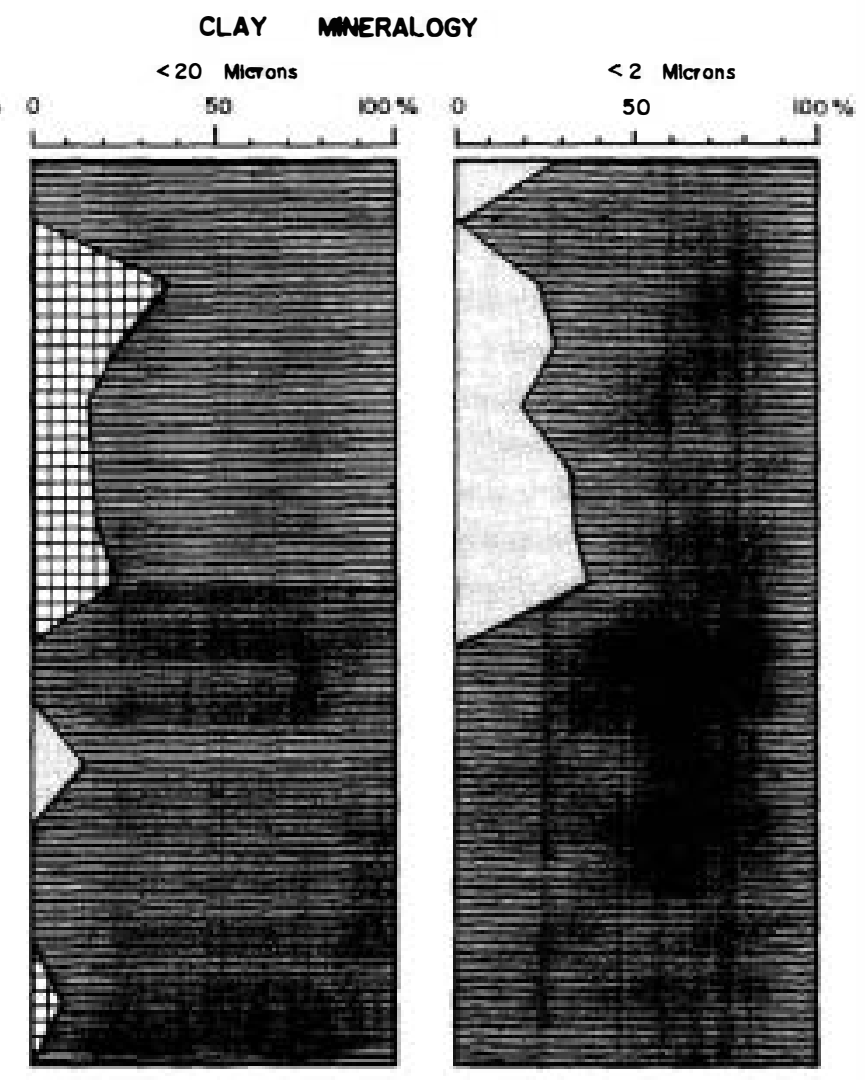

Ë nsMTtте
$=$ R.UTE

VERMICULITE

[I] PYROPHYLLITE

Fig. 9. Bulk mineralogy and evolution of the clay mineral assemblage of the Marines Formation. See also Table 2 for a more detailed sedimentological description of the section.

ing near the top of the upper conglomerates unit (Fig. 6). This trend can be explained by the sedimentological evolution proposed by López-Gómez and Arche (1993a): retrograding alluvial fans controlled by backfaulting and increasing transport distance with time. The pyrophyllite disappears completely during sediment transport in the upper, more distal unit when it evolves to fluvial.

Kaolinite is typical of low-temperature conditions, as indicated by its occurrence as a residual weathering product and in low-grade diagenetic settings (Ehrenberg et al., 1993). In the studied materials, the presence of kaolinite in substantial percentages is related to the development of kaolinitic saprolites in the Palaeozoic basement of the source area; the climate was humid, at least seasonally, with heavy rains, and moderate to high temperature, and never of desert type. This palaeoenvironmental interpretation is supported by sedimentological data such as the massive or cross-bedded nature of the conglomerates, the scarcity of the matrix and the pebble-supported fabric, indicating deposition from running-water in braided rivers under wet, possibly seasonal climate; the absence of debris and mud-flows is against a sedimentary process developed in an arid climate. Palaeontological data, such as the presence of plant remains and pollen assemblages, also indicate a humid environment at least in the fan areas. Comminuted vascular plant remains are 


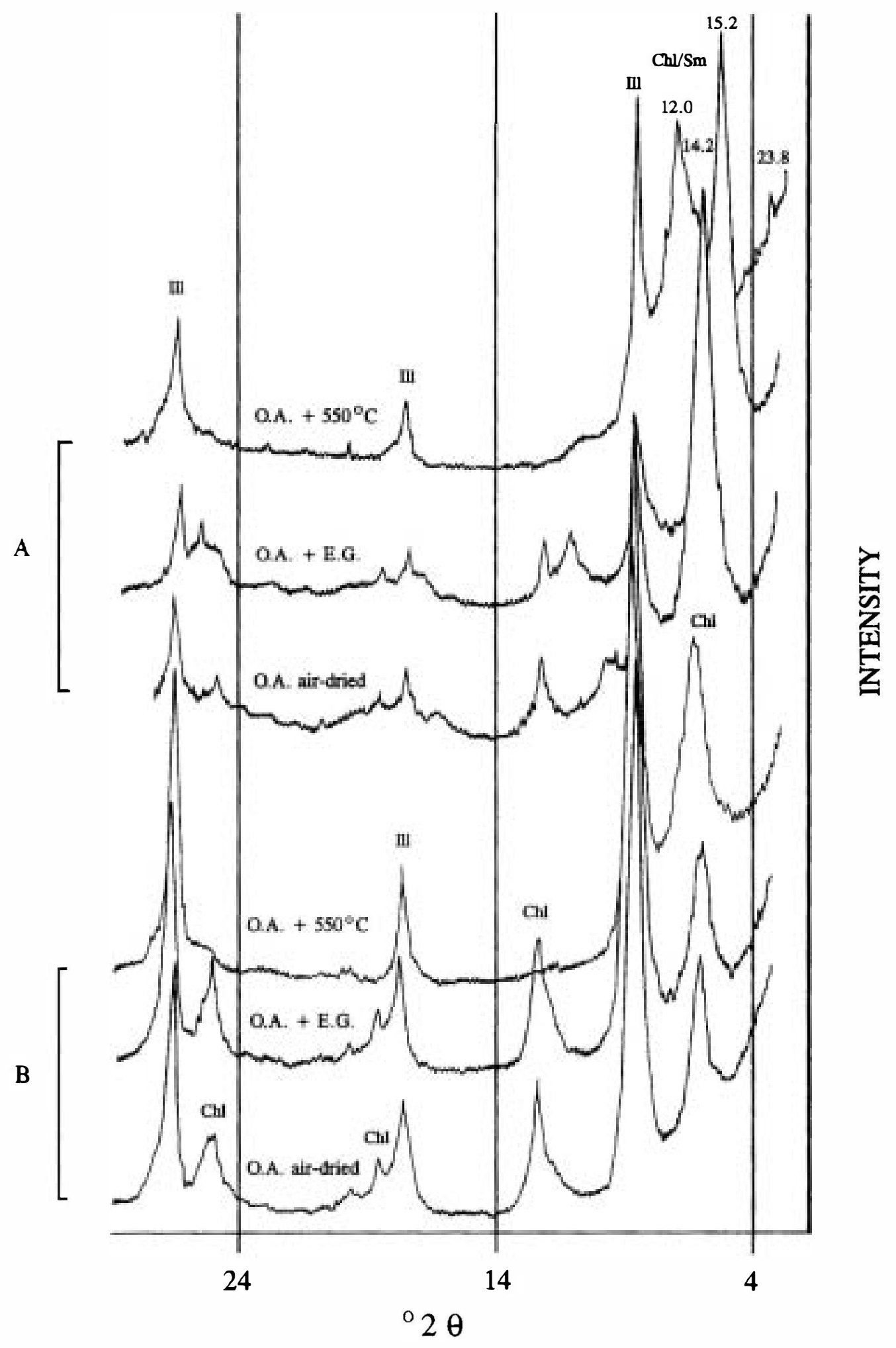


very common in the sandst one wedges interpreted as waving-stage channel deposits. Under these conditions, advanced chemical weathering would favour the leaching of most of the cations and kaolinite would be a residual mineral. Our data and interpretations are similar to those of Fisher and Jeans (1982) for the Permian Red Beds offshore Devon, U.K.

\subsection{Second group}

The clay mineralogy of the Alcotas and Cañizar Formations consists exclusively of illite, in spite of the unconformity that separates both units (the only case in the Permian and Triassic sediments of the area). The low IC values measured in these samples, together with the predominant presence of the $2 \mathbf{M}_{1}$ polytype, indicate that illites in these samples are mainly detrital, although a small proportion of authigenic illites (with a higher proportion of the $1 \mathrm{M}$ polytype) have been recognized in the $<2-\mu \mathrm{m}$ fraction.

The palaeogeographic reconstructions show a progressive widening of the sedimentary basin and more remote source areas, probably in the metamorphic core of the Iberian Massif (Fig. 11, I), to the west of the Iberian Basin. The drainage was longitudinal, with transverse supply reduced to a minimum, and the basin opened to the Tethys sea during the sedimentation of the Cañizar Formation (López-Gómez and Arche, 1993b).

The illitic nature of the clay fraction indicates that illite was very abundant in the source area during a long period of time during active erosion. We interpret the presence of illite as the sole component of the clay fraction of the Alcotas and Cañizar Formations as the consequence of long weathering processes in the high metamorphicgranitic source area to the NW (the IBM in Fig. 1B) under semi-arid, seasonal conditions (Fig. 11, I). The long fluvial transport allows for repeated erosion-sedimentation cycles and the total destruction of clays other than illite in an aqueous environment. Recently, Jeans et al. (1994) have proposed the possibility of an aeolian dust input coming from the German-Polish Zechstein basin as an alternative source for illite. This suggestion is difficult to prove, but it is a clear possibility as the clockwise anticyclonic wind pattern would provide a feasible transport mechanism.

\subsection{Third group}

The Eslida Formation represents a major readjustment in the geometry of the basin and its drainage pattern. The areal extent was reduced, a depocenter was created in the NE margin and palaeocurrents from the $\mathrm{N}$ were dominant (LópezGómez and Arche, 1994; Arche and López-Gómez, 1996) (Fig. 11, II). The presence of pyrophyllite (Fig. 8 ) in this formation accompanying the dominant illite in the clay fraction can be readily explained as the main source area was the uplifted Palaeozoic metamorphic basement along the Ateca-Montalbán-Maestrazgo high (Fig. 1A), and transport was very short by southward-flowing rivers (Fig. 11, II). The presence of pyrophyllite in the Ateca-Montalbán-Maestrazgo Palaeozoic slates has been proven (Fig. 4) and is the obvious source of this mineral.

The change in source area from the SW and NW to the NE basin margin is a response to repeated basin extension (Fig. 11) and the migration of the depocenters away from the original basin boundary fault (Arche and López-Gómez, 1996), as predicted in the models of Gibbs (1984). The short transport and rapid burial, especially in the lower part of the formation made preservation of pyrophyllite possible. As in the case of the Boniches Formation, pyrophyllite disappears in the more distal facies of the upper part of the Eslida Formation. The activity of this new provenance area was short, coinciding with a progressively development of the Hesse-Burgundy rift during the Anisian (Fig. 1B) (Arche and LópezGómez, 1996). It was also a very short activity

Fig. 10. X-ray diffraction traces of the oriented aggregates for the $<2-\mu \mathrm{m}$ fraction from: (A) sample LD-3 (Landete Formation); and (B) sample MAMG-4 (Mas Formation). Ill=illite; $\mathrm{Chl}=$ chlorite; $\mathrm{Chl} / \mathrm{Sm}=$ mixed-layer chlorite/smectite. O.A. air-dried =airdried sample; O.A. +E.G. $=$ after ethylene glycol solvation; O.A. $+550^{\circ} \mathrm{C}=$ after heat treatment. Spacing values expressed in $\AA$. 
( CAÑIZAR Fm.)

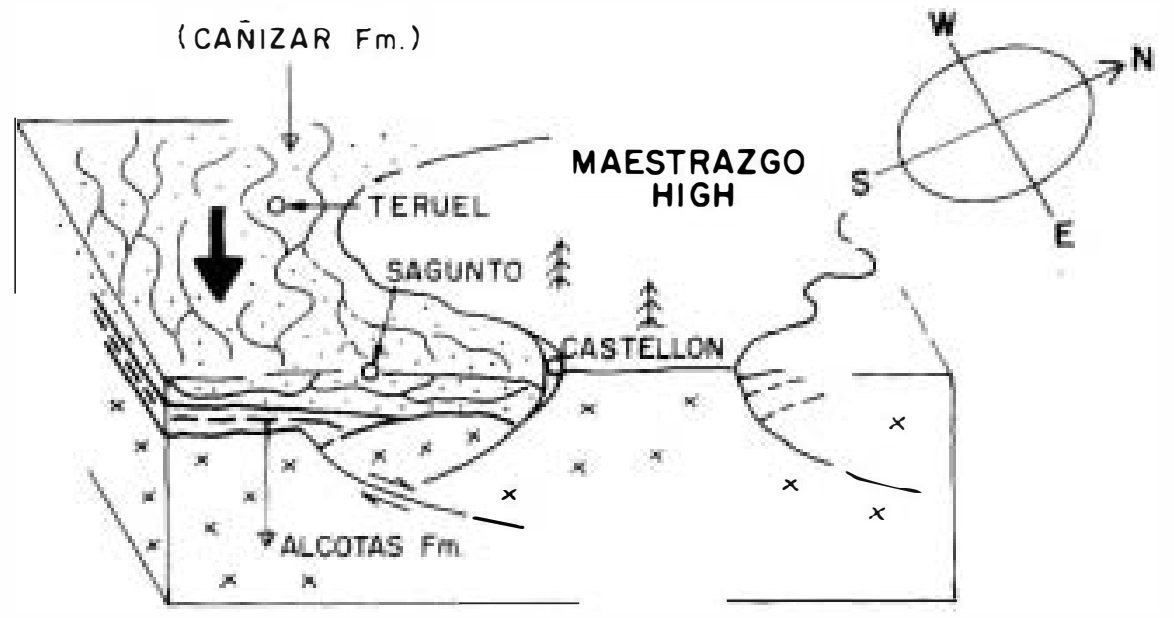

II

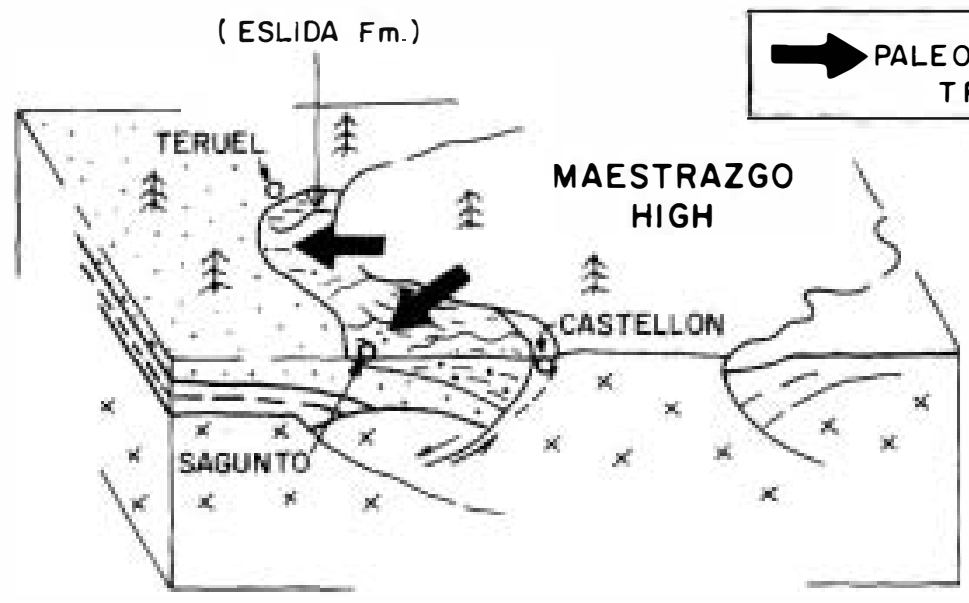

III

(MARINES Fm.)

${ }^{x} \times$ BASEMENT

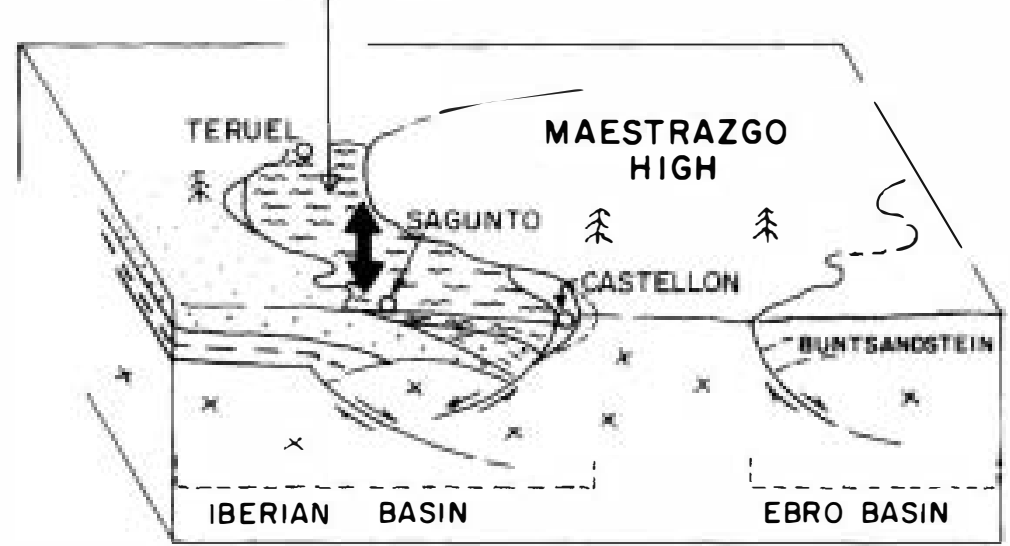


because the very fast subsidence of the area in which the Eslida Formation was deposited allowed the incursion of the Tethys sea represented by the Marines Fm.

As the Eslida Formation is lithologically very similar to the Alcotas Formation and this has led to some confusion in the mapping of some areas of the Mediterranean coast, the clay mineralogy can provide a reliable correlation/discrimination criterion in the absence of pollen and spores, the only available biostratigraphic significant fossils (Boulouard and Viallard, 1982; López-Gómez and Arche, 1992).

\subsection{Fourth group}

This group consists of the Marines, Landete, Mas and Cañete Formations. They represent a drastic change in the mineralogy, the result of an evolution from continental to marine environments (Fig. 11, III), as shown independently by sedimentological data (see discussion in López-Gómez and Arche, 1993a). The detrital clay association of illite, kaolinite and pyrophyllite is succeeded by a clay mineral assemblage of illite, chlorite, vermiculite and regular and irregular mixed-layer chlorite/ smectite, chlorite/vermiculite and illite/chlorite. The presence of some of these mixed-layer clays (chlorite/smectite and chlorite/vermiculite) was originally described in the Röt Formation of the classic Buntsandstein facies near Göttingen, Germany (Lippmann, 1956), of similar age and environment to the Marines Formation studied in this paper.

The continental-marine transition takes place in the Marines Formation, which is still almost entirely siliciclastic. The lower part contains illite with traces of mixed-layer illite/chlorite and chlorite/vermiculite, but in the upper half chlorite is present in the $2-20-\mu \mathrm{m}$ fraction and vermiculite in the $<2-\mu \mathrm{m}$ fraction (Fig. 9); the latter can be interpreted as an oxidation product of the former, by a vermiculitization process in oxidizing estuarine and very shallow-marine environments. The experimental transformation of chlorite into vermiculite by reaction in saturated bromine water has been documented by Ross (1975).

Thus, there is a vertical evolution in the clay mineral assemblages of this formation from illites and mixed-layer clays into Mg-chlorites. The detrital illites coming from the continental source areas were deposited in a shallow-marine hypersaline environment and experienced an early environment-related diagenesis. The most degraded illites fixed $\mathrm{Mg}$ and formed mixed-layer clays that evolved vertically to chlorites when passing to more marine environments, in a similar way to that described by Lucas (1962) and Lucas and Ataman (1968) for the Triassic sediments of the French Jura. Thus, the presence of chlorite and mixed-layer clays in these samples can be considered as the first indication of a marine-related environment. However, when dolomite is present it fixes the $\mathrm{Mg}$, inhibiting the formation of chlorite. This negative correlation between chlorite and dolomite is a primary or very early diagenetic feature as a detailed petrologic study confirms. The calcite present in the formation is a dedolomitization product (López-Gómez et al., 1993). An alternative explanation for the origin of these chlorites is that they were formed during burial diagenesis by reaction among dioctahedral clay minerals, quartz and dolomite, as it was described by Hillier (1993) for the lacustrine mudrocks in the Orcadian basin. Such a reaction was postulated by Hutcheon et al. (1980) as follows:

$$
\begin{aligned}
& 5 \text { dolomite }+2 \text { illite }+3 \text { quartz }+11 \mathrm{H}_{2} \mathrm{O} \rightarrow \\
& 3 \text { chlorite }+15 \text { calcite }+2 \mathrm{~K}^{+}+2 \mathrm{OH}^{-}+15 \mathrm{CO}_{2}
\end{aligned}
$$

Accordingly, the mutually exclusive relationship found in the rocks studied in our work between chlorite and dolomite is in good agreement with

\footnotetext{
Fig. 11. Tentative reconstruction in stages I-III of the palaeogeographical evolution of the Alcotas, Cañizar, Eslida and Marines Formations for the easternmost border of the study area. See Fig. 1 for the present and palaeogeographical locations and Fig. 2 for the stratigraphical arrangement of the units. Observe how the palaeocurrent trend changes correspond with the main changes in the clay mineralogy showed in Figs. 5, 6,8 and 9. Stage III shows an exchange between continental and marine waters and sediments.
} 
this origin. Nevertheless, the above reaction would involve an important increase in the percentage of calcite and presumably of $\mathrm{K}$-feldspar in those samples containing chlorite, and there is no evidence for such change in the mineral associations of the Marines Formation (Fig. 9). Although with the data available there is not a concluding criterion to discriminate between the syngenetic (or early diagenetic) and the burial diagenetic hypotheses, we propose the former model as the most likely explanation of the observed clay mineral association for this formation, because of the absence of $\mathrm{K}$-feldspar and calcite in the percentages required by the deep burial diagenesis model. However, the clay mineral assemblage can be used in both cases as an indicator of a marine sedimentary environment, since the initial presence of dolomite would be necessary for the Mg-rich clays to form in the burial diagenetic model.

The Landete, Mas and Cañete Formations present a comparable vertical evolution of the clay minerals, with illite and mixed-layer clays evolving into $\mathrm{Mg}$-chlorites. The presence of $\mathrm{Mg}$-rich clays is not an unequivocal proof of a marine origin. They are present in continental deposits such as the Mercia Mudstone Group (Upper Triassic) of England (Leslie et al., 1993; Wright and Sandler, 1994; Talbot et al., 1994), the East Berlin Formation (Early Jurassic U.S.A.) (GierlowskiKadesh and Rust, 1994), and recent lacustrine deposits of Central Australia and Sudan (Morgan. 1993; Jacobson et al., 1994; Salama, 1994), but the presence of marine fossils in the Landete, Mas and Cañete Formations rules out this interpretation.

The analytical results, summarized in Fig. 5. show clearly that each depositional sequence, with the excep tion of DS-2, has a characteristic distribution of clay minerals ( Fig. 12), so that the sequence bounding unconformities mark sharp changes in the clay mineral assemblages. Thus, the original clay mineralogy of each formation can be inferred in spite of important late diagenetic changes. The main controls on the clay mineralogy were extrabasinal, notably weathering processes and the petrologic nature of the source area and intrabasinal, such as the sedimentary environments and types and duration of the transport processes.
According to the IC data, most of the samples fall within the diagenetic realm ( IC $>0.42^{\circ} \Delta 2 \theta$ ). However, the slightly lower "crystallinity" values measured in the continental sediments probably reflect the presence of small amounts of detrital illites in the $<2-\mu \mathrm{m}$ fraction. Furthermore, the presence of carbonates in the marine sediments would have delayed the illitization process, resulting in higher IC values than in the non-calcareous samples (Alonso-Azcárate et al., 1995). The increase in the "crystallinity" observed in some samples from the Eslida and Marines Formations is related to an important Alpine horizontal detachment along the Middle Triassic, between the Lower Palaeozoic to Lower Triassic materials and the Late Triassic-Jurassic cover. The "crystallinity" of the illite was probably modified due to the pressure and temperature increase during this active period, as demonstrated by Roberts et al. (1991) and Fernández-Caliani and Galán (1992) for the Corris Slate Belt and the Iberian Pyrite Belt, respectively.

\section{Conclusions}

(1) The continental Permian--Lower Triassic sediments of the SE Iberian Ranges contain an association of illite \pm kaolinite \pm pyrophyllite, and the shallow-marine Middle-Late Triassic sediments of illite \pm chlorite \pm vermiculite \pm mixed-layer clays.

(2) The clay mineral associations of each formation reflect the original clay assemblages, in spite of late diagenetic changes.

(3) The Tabarrena, the Boniches and the Eslida Formations contain substantial amounts of pyrophyllite, an anchizone mineral reworked from the Palaeozoic metamorphic basement outcropping in the SW and NE margins of the basin into the alluvial fan and fluviatile sediments.

(4) Illite in the Alcotas and Cañizar Formations comes from a high-metamorphic, granitic source area in the NW. The input of desert dust coming from the Boreal basin is possible, but not proven.

(5) Mg-rich clay minerals in the Marines, Cañete, 


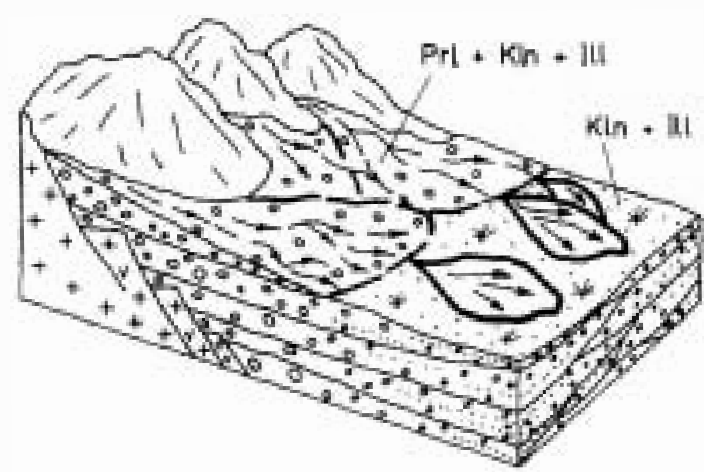

Age: Thüringian (Upper Permian)

Fm.: Boniches Conglomerates.

$$
\mid \begin{aligned}
& \text { Prl - Pyrophyllite } \\
& \text { Kln - Kaolinite } \\
& \text { Ill - Illite }
\end{aligned}
$$

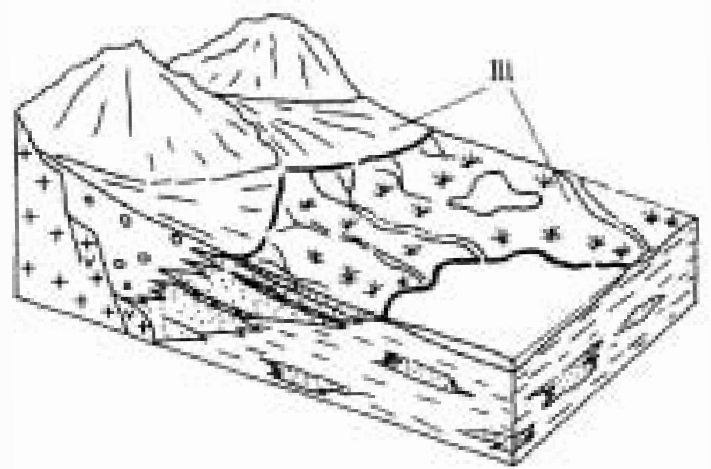

\section{STAGE B :}

Age: Thüringian (Upper Permian)

Fm.: Alcotas Mudstones and Sandstones.

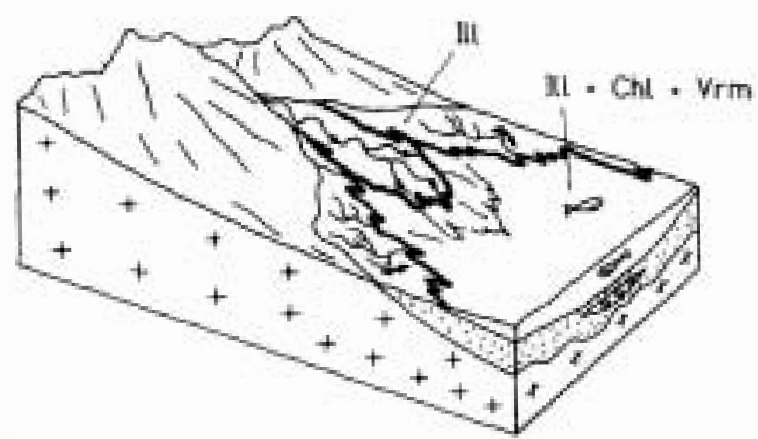

STAGE C :

Age: Anisian (Middle Triassic)

Fm.: Marines Clays, Mudstones and Marls.

Chl - Chlorite
Vrm - Vermiculite
ML - Mixed - layer clays

STAGE D :

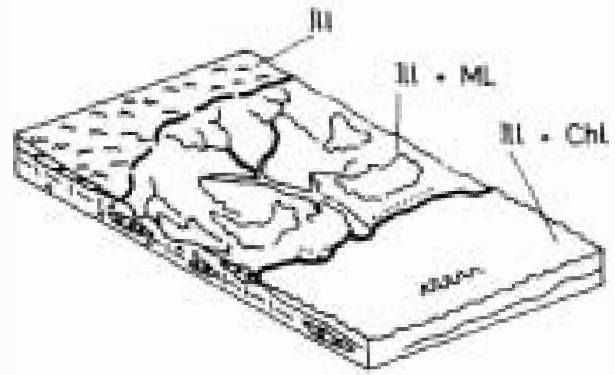

Age: Anisian - Ladinian

(Middle Triassic)

Fms.: Landete Dolomites.

Mas Mudstones, Marls

and Gypsum.

Cañete Dolomites

and Limestones.

Fig. 12. Tentative palaeogeographical reconstruction and locations of the clay mineral assemblage for each differentiated stage. See also Fig. 2 for a more detailed stratigraphical information. 
Landete and Mas Formations are related to shallow-marine environments, with seawater causing a very early diagenesis of the detrital clays carried by the rivers into the basin. A continental origin is excluded by the presence of marine fossils and sedimentological data.

(6) In the absence of fossil evidence, clay mineralogy is an useful method of correlation discrimination among continental and shallow-marine Permian and Triassic formations of the SE Iberian Ranges, in good agreement with other palaeoenvironmental interpretation methods.

(7) Clay mineralogy analysis can clearly improve the knowledge about palaeogeographical evolution, that would include source areas and coastline changes, of the westernmost border of the Tethys basin during the first incursion of the Tethys sea.

(8) There is a clear relationship between the clay mineral assemblages and the main palaeogeographical stages of evolution of the basin in the studied area and in the westernmost coastline of the Tethys basin during the Permian Triassic transition.

(9) The clay mineralogical study backs up the data of climate evolution in an interval (Permian-Triassic) of marked change in the western Tethys area, especially in sediments which lack fossils.

\section{Acknowledgements}

We thank Carlos Sánchez for drawing the figures. This is a contribution to Projects PB92-0041 and PB95-0084 financed by the DGICYT, Ministry of Education Research, Spain. The manuscript was improved by the comments of S. Hillier, an anonymous referee and F. Surlyk as editor.

\section{References}

Alonso-Azcárate, J.. Barrenechea, J.F., Rodas, M.. Mas, J.R.. 1995. Comparative study of the transition between very lowgrade and low-grade metamorphism in siliciclastic and car- bonate sediments: Early Cretaceous, Cameros Basin. Clay Miner. 30, 407419

Arche. A.. López-Gómez. J., 1996. Origin of the Permian and Triassic Iberian Basin. Central Spain. Tectonophysics 266. $44.3-464$.

Arribas, J., 1984. Sedimentologia y diagénesis del Buntsandstein y Muschelkalk de la rama Aragonesa de la Cordillera Ibérica (provincias de Soria y Zaragoza). Ph.D. Thesis, Universidad Complutense de Madrid, Madrid, 621 pp.

Boulouard. Ch., Viallard. P.. 1982. Réduction ou lacune du Trias inférieur sur la bordure mediterranéenne de la Chaîne Iberique: arguments palynologiques. C.R. Acad. Sci.. Paris $295,803 \cdot .808$

Caballero, M., Martin-Vivaldi. J.L., 1972. Distribution of clay minerals in the Spanish Triassic sedimentary basins. Int. Clay Cont: Madrid 1, 313-324.

Caillére, S., Henin, S., Rautureau, M., 1982. Minéralogic des argiles, 1. Structure et propiétés physico-chimiques, 2nd ed. Masson, Paris, 184 pp.

Castillo, F., 1974. Le Trias évaporitique des bassins de la Vallée del Ebre et de Cuenca. Bull. Soc. Géol. Fr. 16, 49-63.

Doubinger, J., López-Gómez, J., Arche, A., 1990. Pollen and spores from the Permian and Triassic sediments of the Southeastern Iberian Ranges, Cueva de Hierro (Cuenca) to Chelva Manzanera (Valencia- Teruel) region, Spain. Rev. Paleobot. Palynol. 66. 2545

Ehrenberg. S.N., Aagaard, P.. Wilson, M.J., Fraser, A.R., Duthie. D.M.L.. 1993. Depth-dependent transformation of kaolinite to dickite in sandstones of the Norwegian continental shelf. Clay Miner. 28, 325352.

Fernández-Caliani. J.C., Galán, E., 1992. Influence of tectonic factors on illite crystallinity: a case study in the Iberian pyrite belt. Clay Miner. 27. 385-388.

Fisher, M.J., Jeans, C.V., 1982. Clay minerals stratigraphy in the Permo-Triassic Red-bed sequences of BNOC72/I0-IA. Western Approaches, and the South Devon coast. Clay Miner. 17. 79-89.

Gibbs, A.D., 1984. Structural evolution of extensional basin margins. J. Geol. Soc. London 141, 609-620.

(jierlowski-Kadesh. E., Rust. B.. The Jurassic East Berlin Formation. Hartford Basin. Newark Supergroup (Connecticut-Massachusetts): A saline lake-playa-alluvial plain system Sedimentology and geochemistry of modern and ancient saline lakes. 1994. SEPM Spec. Publ. 50, 249- 265.

Hayes, I.B., 1970. Polytypism of chlorite in sedimentary rocks. Clays Clay Miner. 18, 285306.

Hillier, S.. 1993. Origin, diagenesis and mineralogy of chlorite minerals in Devonian lacustrine mudrocks, Orcadian Basin. Scotland. Clays Clay Miner. 41, 24(). 259.

Hutcheon, I., Oldershaw, A., Ghent, E.D., 1980. Diagenesis of Cretaceous sandstones of the Kootenay Formation at Elk Valley (southeast British Columbia) and Mt Allan (southwestern Alberta). Geochim. Cosmochim. Acta 44. 142514.35 .

Jacobson, G.. Ferguson, J., Ray-Evans, W., 1994. Groundwater discharge playas of the Mallee region. Murray basin, southeast Australia. In: Rosen. M.R. (Ed.), Paleoclimate and 
Basin Evolution of Playa Systems: Boulder, Colorado. Geol. Soc. Am., Spec. Pap. 289, 81-96.

Jeans, C.V., Mitchell, J.G., Scherer, M., Fisher, M.J., 1994. Origin of the Permo-Triassic clay mica assemblage. Clay Miner. 29, 575-589.

Kisch, H.J., 1991. Illite crystallinity: recommendations of sample preparations, $\mathrm{X}$-ray diff raction settings, and interlaboratory samples. J. Metamorphic Geol. 9, 665-670.

Kübler, B., 1967. La cristallinité de l'illite et les zones tout à fait supérieures du métamorphisme - Étages tectoniques. Coll. Neuchâtel, pp. 105-122.

Leslie, A.B., Spiro, B., Tucker, M.E., 1993. Geochemical and mineralogical variations in the Upper Mercia Mudstone Group (Late Triassic), South-West Britain: Correlation of outcrop sequences with boreholes geophysical logs. J. Geol. Soc. London 150, 67-75.

Lippmann, F., 1956. Clay minerals from the Röt member of the Triassic near Göttingen, Germany. J. Sediment. Petrol. 26, $125 \cdots 139$.

López-Gómez, J., Arche, A., 1985. Gravel bars in braided-river channels of basal Buntsandstein-facies conglomerates in the Cuenca Province (Southeastern Iberian Ranges, Central Spain). In: Mader, D. (Ed.), Aspects of Fluvial Sedimentation in the Lower Triassic Buntsandstein of Europe.Berl. Lect. Notes Earth Sci. 4, 65-86.

López-Gómez, J., Arche, A., 1992. Las unidades litoestratigráficas del Pérmico y Triásico Inferior y Medio en el sector SE de la Cordillera Ibérica. Estud. Geol. 48, 123-143.

López-Gómez, J., Arche, A., 1993. Sequence stratigraphic analysis and paleogeographic interpretation of the Buntsandstein and Muschelkalk facies (Permo-Triassic) in the SE Iberian Ranges, E Spain. Palaeogeogr., Palaeoclimatol., Palaeoecol. 103, 179-201.

López-Gómez, J., Arche, A., 1993. Architecture of the Cañizar fluvial sheet sandstones, Early Triassic, Iberian Ranges, eastern Spain. In: Marzo, M., Puigdefábregas, C. (Eds.), Alluvial Sedimentation. Int. Assoc. Sedimentol., Spec. Publ. 17, 363-382.

López-Gómez, J., Arche, A., 1994. El Triásico y Pérmico del SE de la Cordillera Ibérica. In: Arche, A. (Ed.), Field Trip Guide, III Coloquio sobre el Pérmico y Triásico de la Peninsula Ibérica, Cuenca, pp. 1-70.

López-Gómez, J., Mamet, B., 1990. Sedimentology and petrology of the Cañete Dolomites and Limestones Formation (Muschelkalk Facies, Middle to Upper Triassic), Southern Iberian Ranges, Eastern Spain. Facies 23, 1-16.

López-Gómez, J., Mas, R., Arche, A., 1993. The evolution of the Middle Triassic (Muschelkalk) carbonate ramp in the SE Iberian Ranges, Eastern Spain: sequence stratigraphy, dolomitization processes and dynamic controls. Sediment. Geol. $87,165-193$.

Lucas, .I. 1962. La transformation des minéraux argilleux dans la sédimentation - Études sur les argiles du Trias. Mém. Serv. Carte Géol. Alsace Lorraine 23, 202p

Lucas, J., Ataman, G., 1968. Mineralogical and geochemical study of clay mineral transformations in the sedimentary Triassic Jura basin (France). Clays Clay Miner. 16, 365-372.
Marfil, R., Bonhomme, M.G., de la Peña, J.A., Penha dos Santos, R., Sell, I., 1996. La edad de las ilitas en areniscas pérmicas y triásicas de la Cordillera Ibérica mediante el método K/Ar: Implicaciones en la historia diagenética y evolución de la Cuenca. Cuad. Geol. Ibér. 20, 61-84.

Márquez, L., López-Gómez, J., Trifonova, E., 1994. Datación (foraminiferos) y ambientes sedimentarios de la Formación Dolomias de Landete, Anisiense, Facies Muschelkalk, provincia de Cuenca. Bol. R. Soc. Esp. Hist. Nat. 89, 99-107.

Morad, S., Marfil, R., de la Peña, J.A., 1989. Diagenetic $\mathrm{K}$-feldspar pseudomorphs in the Triassic Buntsandstein of the Iberian Range, Spain. Sedimentology 36, 635-650.

Morad, S., Al-Aasm, I.S., Ramseyer, K., Marfil, R., Aldahan, A.A., 1990. Diagenesis of carbonate cements in Permo-Triassic sandstones from the Iberian Range, Spain: evidence from chemical composition and stable isotopes. Sediment. Geol. 67, 281-295.

Morgan, K.H., 1993. Development, sedimentation and the economic potential of the paleoriver system of the Yilgarn craton of Western Australia. Sediment. Geol. 85, 637-656.

Roberts, B., Merriman, R.J., Pratt, W., 1991. The influence of strain, lithology and stratigraphical depth on white mica (illite) crystallinity in mudrocks from the vicinity of the Corris Slate Belt, Wales: implications for the timing of metamorphism in the Welsh Basin. Geol. Mag. 128, 633--645.

Robinson, D., Warr, L.N., Bevins, R.E., 1990. The illite "crystallinity" technique: a critical appraisal of its precision. J. Metamorphic Geol. 8, 333-344.

Ross, G.J., 1975. Experimental alteration of chlorites into vermiculites by chemical oxidation. Nature (London) 225, $133-134$.

Ruiz Cruz, M.D., 1996. Criterios mineralógicos empleados en el análisis del Permotrias Maláguide. Cuad. Geol. Ibér. 20. 37-60.

Ruiz Cruz, M.D., Caballero, M.A., 1976. Caracteristicas mineralógicas, genéticas y distribución de los minerales de la fracción fina del Trias de la Cordillera Ibérica, I. Caolinita y dickita. Bol. Geol. Min. 87, 47-56.

Ruiz Cruz, M.D., Caballero, M.A., 1976. Caracteristicas mineralógicas, genéticas y de distribución de los minerales de la fracción fina del Trias de la Cordillera Ibérica, II. Illita y mica. Bol. Geol. Min. 87, 177-184.

Ruiz Cruz, M.D., Caballero, M.A., 1976. Caracteristicas mineralógicas, ganéticas y distribución de los minerles de la fracción fina del Trías de la Cordillera Ibérica, Ill. Clorita, montmorillonita y vermiculita. Bol. Geol. Min. 87, 284-291.

Ruiz Cruz, M.D., Caballero, M.A., 1976. Características mineralógicas, genéticas y distribución de los minerales de la fracción fina del Trias de la Cordillera Ibérica, IV. Minerales interestratificados. Bol. Geol. Min. 87, 409-417.

Salama, R.B., 1994. The evolution of saline lakes in the relict drainage of the Yilgarn River, W Australia --. Sedimentology and geochemistry of modern and ancient saline lakes. SEPM Spec. Publ. 50, 189-199.

Sopeña, A., López-Gómez, J., Arche, A., Pérez-Arlucea, M., Ramos, A., Virgili, C., Hernándo, S., 1988. Permian and Triassic of the Iberian Peninsula. In: Manspeizer, W. (Ed.), 
Triassic--Jurassic Rifting --- Continental Breakup and the Origin of the Atlantic Ocean and Passive Margins. Developments in Geotectonics, 22B. Elsevier. Amsterdam. pp. 757-786.

Talbot, M.R., Holm, K.. Williams, M.A.J.. 1994. Sedimentation in low-gradient desert margin systems: A comparison of the Late Triassic of Northwest Somerset (England) and the Late Quaternary of east-central Australia. Geol. Soc. Am. Bull., Spec. Pap. 289, $97 \cdot 117$.

Warr, L.N., Rice, H.N., 1994. Interlaboratory standardization and calibration of clay mineral crystallinity and crystallite size data. J. Metamorphic Geol. 12, 141152.
Wright, V.P., Sandler, A., 1994. A hydrothermal model for the early diagenesis of Late Triassic alluvial sediments. J. Geol. Soc. London 151, 897-900.

Ziegler, P.A., 1988. Post-Hercynian plate reorganization in the Tethys and Arctic-North Atlantic domains. In: Manspeizer, W. (Ed.), Triassic-Jurassic Rifting - Continental Breakup and the Origin of the Atlantic Ocean and Passive Margins. Developments in Geotectonics, 22B. Elsevier, Amsterdam. pp. $712 \ldots-756$. 